\title{
COMMENTS
}

\section{The Use of Government Judgments in Private Antitrust Litigation: Clayton Act Section 5(a), Collateral Estoppel, and Jury Trial}

Prior to the enactment of the Clayton Act in $1914,{ }^{1}$ a judgment against a defendant in a government antitrust prosecution could not be used as an estoppel against that defendant in a suit later brought by a private plaintiff. The doctrine of mutuality of estoppel, which provides that a judgment may be asserted as an estoppel only by one who would be estopped by that judgment if it had been decided against him, protected the defendant from being estopped from denying that he had violated the antitrust laws. ${ }^{2}$ Section 5(a) of the Clayton Act was designed to aid a private plaintiff bringing suit after a successful government antitrust prosecution by providing that the pricr judgment or decree could be used in the later suit as prima facie evidence of all matters which the judgment "would be an estoppel as between the parties thereto."3

115 U.S.C. $\S \S 12-27$ (1973).

2 See text and notes at notes 30-31 infra; cf. Bigelow v. Old Dominion Copper Co., 225 U.S. 111 (1912). "It is a principle of general elementary law that estoppel of a judgment must be mutual." Id. at 127. See also Buckeye Powder Co. v. E.I. DuPont DeNemours Powder Co., 248 U.S. 53, 63 (1918) (which held that an antitrust judgment rendered prior to the enactment of the Clayton Act was inadmissible in a private suit brought under the Act).

${ }^{3}$ A final judgment or decree heretofore or hereafter rendered in any civil or criminal proceeding brought by or on behalf of the United States under the antitrust laws to the effect that a defendant has violated said laws shall be prima facie evidence against such defendant under said laws or by the United States under section 15a of this title, as to all matters respecting which said judgment or decree would be an estoppel as between the parties thereto: Provided, That this section shall not apply to consent judgments or decrees entered before any testimony has been taken or to judgments or decrees entered in actions under section $15 \mathrm{a}$ of this title.

38 Stat. 731 (1914), as amended, 15 U.S.C. $\$ 16(a)$ (1970).

Section 5 uses the term "estoppel" in a unique way. It is not used in its typical sense to define the effect of a prior judgment but rather to define the circumstances in which the decree is to be admissible as prima facie evidence. Thus the decree is admissible only if it would be admissible as an estoppel if the Government, rather than a private plaintiff, were bringing the subsequent suit. See Shores, Treble Damage Antitrust Suits: Admissibility of Prior Judgments Under Section 5 of the Clayton Act, 54 Iowa L. Rev. 434, 445 (1968) [hereinafter cited as Shores]. The term "estoppel" used in the statute refers to collateral estoppel rather than res judicata. Emich Motors Corp. v. General Motors Corp., 340 U.S. 558, 569 (1951); Michigan v. Morton Salt Co., 259 F. Supp. 35, 65 (D. Minn. 1966) (supplemental 
Section 5(a) gave the private antitrust plaintiff of 1914 a valuable new tool, but the protection it provides has become somewhat unnecessary over time. The doctrine of mutuality of estoppel has lost much of its vitality and it is doubtful whether it would today operate to deny a private plaintiff the benefit of a successful government antitrust prosecution. ${ }^{4}$ Since Congress has determined that private antitrust plaintiffs are a favored class of litigants, one might have expected the courts to have supplemented section 5(a) by allowing a prior successful government judgment to be asserted as an estoppel even in the absence of mutuality. The courts have, nevertheless, consistently maintained that section 5 (a) bars the application of collateral estoppel in this situation. ${ }^{5}$ As a consequence, prior government judgments lack conclusive effect in the private suit and the defendant can introduce evidence to rebut the prima facie case and force the private plaintiff to litigate the case as if the Government had never established a violation. ${ }^{6}$ Thus, in light of the

opinion), aff'd sub nom. Hardy Salt Co. v. Illinois, 377 F.2d 768 (8th Cir.), cert. denied, 389 U.S. 912 (1967); see Note, Closing an Antitrust Loophole: Collateral Effect For Nolo Pleas and Government Settlements, 55 VA. L. REv. 1334, 1335-36 n.6 (1969) [hereinafter cited as VIRginia Note]; Comment, Clayton Act, Section 5: Aid to Treble Damage Suitors? 61 Yale L.J. 417, 420-21 n.15 (1952) [hereinafter cited as YALE CoMmenT].

- See text and notes at notes 30-43 infra.

5 See, e.g., Purex Corp. v. Procter \& Gamble Co., 308 F. Supp. 584 (C.D. Cal. 1970), aff'd on other grounds, 453 F.2d 288 (9th Cir. 1971), cert. denied, 405 U.S. 1065 (1972). The court held that collateral estoppel did not apply to a Federal Trade Commission order in a subsequent civil suit. The court stated: "The Commission order cannot be both prima facie and conclusive; . . ." 384 F. Supp. at 589. See also United States v. Grinnell Corp., 307 F. Supp. 1097 (S.D.N.Y. 1969).

In addition, several courts have assumed but not decided that a prior government judgment could only have prima facie effect under section 5(a). See Sam Fox Publishing Co. v. United States, 366 U.S. 683, 690 (1961); Emich Motors Corp. v. General Motors Corp., 340 U.S. 558, 568 (1951); Richfield Oil Corp. v. Karseal Corp., 271 F.2d 709, 724 (9th Cir. 1959); Deluxe Theatre Corp. v. Balaban \& Katz Corp., 95 F. Supp. 983, 986 (N.D. Ill. 1951).

- A government decree introduced as prima facie evidence is, by itself, sufficient to sustain a judgment on the issues for which it is submitted even though it only shifts the burden of coming forward with evidence and not the burden of proof. When the defendant comes forward with rebuttal evidence, as will typically be the case, the case proceeds much as if the decree were never introduced. Michigan v. Morton Salt Co., 259 F. Supp. 35, 65 (D. Minn. 1966) (supplemental opinion), aff'd sub. nom. Hardy Salt Co. v. Illinois, 377 F.2d 768 (8th Cir.), cert. denied, 389 U.S. 912 (1967). The Supreme Court has recognized that the prima facie provisions of section 5(a) are often "of limited practical value." Minnesota Mining \& Mfg. Co. v. New Jersey Wood Finishing Co., 381 U.S. 311, 319 (1965); see VIRGinia NotE, supra note 3, at 1352; YALE CoMmENT, supra note 3, at 420 n.14. As one commentator has remarked:

Despite language in cases which indicates that the purpose of Section $5(a)$ is to give private litigants a formidable weapon, its actual accomplishments may be somewhat less potent. In no way does it measurably decrease the overwhelming task of discovery-the long, tortuous process in which often scores of lawyers are engaged for years in ferreting out facts in what is now termed "waves of discovery." Nor has the experience shown that it either decreases the length of time from inception to ultimate disposition of an antitrust case or the actual length of trial. 
general decline of the mutuality principle, section 5(a) has come to be a detriment to the very parties it was designed to benefit. ${ }^{7}$

This comment will examine the applicability of the principle of collateral estoppel when a private plaintiff attempts to rely on a prior successful government antitrust prosecution. After examining the text and legislative history of section 5(a) of the Clayton Act, the comment argues that Congress did not intend to foreclose the application of collateral estoppel in this situation. Since Congress did not, on the other hand, indicate how collateral estoppel was to be applied, the comment then tests each of the wide range of judgments that may be obtained by the Government against settled principles of collateral estoppel and determines the suitability of estoppel in each case. Finally, this comment addresses the potential argument concerning the right to jury trial that may be raised by recognition of collateral estoppel in this context and concludes that application of collateral estoppel will not impermissibly impair this right.

\section{The Legislative History of Section 5(a)}

Section 5(a) of the Clayton Act does not on its face indicate whether a judgment against a defendant in a government antitrust prosecution can or should collaterally estop that defendant from denying the violation in a subsequent private action. The courts, however, have been willing to assume that it cannot, reasoning that since Congress has decided that a judgment obtained by the

Korman, The Antitrust Plaintiff Following in the Government's Footsteps, 16 VILL. L. REv. 57, 69 (1970) [hereinafter cited as Korman].

This anomaly has not gone unnoticed:

It is thus ironic that the very section originally intended to assist private plaintiffs in their use of government actions may operate instead to prevent application of new judicial concepts for their benefit.

Korman, supra note 6, at 85 . Korman and several other commentators have argued that the Clayton Act should be amended to make prior government judgments conclusive evidence in later private actions. See id. at 84-85; Comment, Proposed Amendment to Section 5(a) of Clayton Act Would Increase Evidentiary Aid for Subsequent Litigants, 39 N.Y.U.L. REv. 518 (1964); Yale Comment, supra note 3, at 425. For a thorough discussion of the amendments to the Clayton Act proposed in 1965 to this effect, see Virginia Note, supra note 3. This comment, on the other hand, argues that courts can give government judgments collateral estoppel effect without waiting for an amendment to the Clayton Act. See text and notes at notes 8-29 infra. Although it might be argued that congressional consideration and rejection of a proposal to accord government judgments collateral estoppel effect demonstrates that Congress does not desire such a result, it is a basic maxim of statutory construction that later expressions of intent cannot alter the original legislative intent. See, e.g., Regional Rail Reorganization Act Cases, 419 U.S. 102 (1974). Since the 1965 amendments never made it out of committee, it would be difficult to determine the intent of the entire Congress with regard to collateral estoppel in this context. 
Government shall have prima facie effect, such a judgment can not also have conclusive effect. ${ }^{8}$ But section 5 (a) does not state that the government judgment shall merely serve as prima facie evidence; its language can plausibly be read as mandating that such a judgment shall have at least prima facie effect, thus leaving the courts the discretion to determine whether to give the judgment the conclusive effect of collateral estoppel. Since an ambiguity appears on the face of the statute, it is appropriate to examine the legislative history of the Clayton Act to determine if Congress intended to preclude the application of collateral estoppel in this situation.

Section 5(a) was included in the Clayton Act to facilitate more vigorous private enforcement of the antitrust laws. Even though the Government had successfully prosecuted several major cases under the Sherman Act, these prosecutions were rarely followed by private suits, ${ }^{10}$ largely, it was believed, because private litigation was so expensive. ${ }^{11}$ In response to a plea by President Wilson to ease the burden on the private antitrust plaintiff, ${ }^{12}$ the House Judiciary Committee proposed legislation that would have made a government antitrust judgment conclusive in a subsequent private action against the same defendant. ${ }^{13}$ Out of "fairness" to the defendant, 14

See cases cited at note 5 supra.

- Prior to the Clayton Act, 38 Stat. 730, 15 U.S.C. $\$ \S 12-27$ (1973), the only federal antitrust statute was the Sherman Act, 26 Stat. 209, 15 U.S.C. $\$ \S 1-7$ (1973), enacted in 1890. The Clayton Act was passed in 1914 in order to provide a more precise statutory enumeration of antitrust violations. See R. Posner, ANtitrust CASES, Economic Notes, aNd Other Materials 29 (1974).

10 In the twenty-four years between the adoption of the Sherman Act and the Clayton Act, only forty-six private antitrust actions were filed and, of these, only four were successful. See Virginia Note, supra note 3, at 1336-37 n.8; Hardy, The Evisceration of Section 5 of the Clayton Act, 49 Geo. L.J. 44, 45-46 (1960) [hereinafter cited as Hardy].

" 51 Cong. Rec. 9090 (1914) (remarks of Rep. Mitchell); 51 Cong. Rec. 9270 (1914) (remarks of Rep. Carlin); 51 Cong. REc. 9490 (1914) (remarks of Rep. Floyd); 51 Cong. REc. 9492-93 (1914) (remarks of Rep. Lenroot).

12 President Wilson declared:

I hope that we shall agree in giving private individuals . . . the right to found their suits for redress upon the facts and judgments proved and entered in suits by the Government where the Government has . . . won . . . . It is not fair that the private litigant should be obliged to set up and establish again the facts which the Government has proved.

H.R. Doc. No. 625, 63d Cong., 2d Sess. 8 (1914).

is The original House bill provided:

That whenever in any suit or proceeding in equity hereafter brought by or on behalf of the United States under any of the antitrust laws there shall have been rendered a final judgment or decree to the effect that a defendant has [violated] . . . any of the antitrust laws, said judgment or decree shall, to the full extent to which such judgment or decree would constitute in any other proceeding an estoppel as between the United States and such defendant, constitute in favor of or against such defendant conclusive evidence of the same facts, and be conclusive as to the same questions of law in favor of or against any other party in any action or proceeding brought under or involving the 
however, the Committee bill went further than President Wilson's proposal and proposed making the result in the government action conclusive in subsequent suits even if the earlier judgment was in favor of the defendant. ${ }^{15}$

When the Committee bill came before the House for consideration, many Congressmen were seriously concerned that it violated due process because it would estop a plaintiff who had never had a "day in court" from litigating his claim if the defendant had prevailed in the government action. ${ }^{16}$ Sentiment in the House favored instead providing for a one-way estoppel that would preclude the defendant from relitigating an issue adversely determined in the government action but that would not prevent a private plaintiff from litigating a claim the Government had pressed unsuccessfully. ${ }^{17}$ Even though some Representatives questioned whether even such a modified provision would be constitutional in light of the principle of mutuality of estoppel, ${ }^{18}$ the House approved and sent to the Senate a bill providing that a prior government judgment would be conclusive in favor of, but not against, a private plaintiff. ${ }^{19}$

The Senate Judiciary Committee, however, had grave doubts regarding the constitutionality of the House bill even though the Committee approved its basic policy. ${ }^{20}$ To avoid due process problems, it recommended that prior government judgments be given only prima facie rather than conclusive effect in subsequent private actions. ${ }^{21}$ When the House bill, accompanied by this recommendation, was referred to the Senate floor, debate again focused on its constitutionality under the mutuality requirement. Although some Senators believed the House bill was constitutional, ${ }^{22}$ a majority, though again in favor of aiding private litigants, found an insurmountable obstacle in the principle of mutuality of estoppel. ${ }^{23}$ Thus

provisions of any of the antitrust laws.

51 Cong. REC. 9200 (1914) (emphasis added).

is 51 Cong. Rec. 9270 (1914) (remarks of Rep. Carlin).

is See note 10 supra. The two-way estoppel aspect of the bill was fully understood. 51 Cong. Rec. 9073 (1914) (remarks of Rep. Webb); 51 CoNG. REc. 9090 (1914) (remarks of Rep. Mitchell); 51 Cong. REc. 9165 (1914) (exchange between Rep. Scott and Rep. Floyd).

is See, e.g., 51 Cong. REc. 9200 (1914) (remarks of Rep. Green); 51 Cong. REc. $9491-92$ (1914) (remarks of Rep. Prouty).

17 See, e.g., 51 Cong. REc. 9079 (1914) (remarks of Rep. Volstead). See also 51 Cong. REc. 9201 (1914) (remarks of Rep. Green).

${ }^{18} 51$ Cong. Rec. 9487 (1914) (remarks of Rep. Volstead); 51 Cong. REc. 9491 (1914) (remarks of Rep. Green).

1951 Cong. Rec. 9911 (1914).

${ }^{20}$ S. Rep. No. 698, 63d Cong., 2d Sess. 45 (1914).

${ }^{21}$ Id.

22 See, e.g., 51 Cong. Rec. 13851 (1914) (remarks of Senator Walsh).

${ }^{23} 51$ ConG. REc. 13853 (1914) (remarks of Senator Chilton); 51 Cong. REc. 13854 (1914) 
uncertainty regarding the constitutionality of one-way estoppel coupled with a strong desire to give private litigants some relief, ${ }^{24}$ motivated the Senate ${ }^{25}$ and later the House ${ }^{26}$ to accept the recommendation of the Senate Judiciary Committee to make a successful government judgment only prima facie evidence of a violation of the antitrust laws.

Congress did not, therefore, as some courts have assumed, ${ }^{27}$ intend to withhold collateral estoppel effect from government antitrust prosecutions by providing that successful judgments would be prima facie evidence in subsequent private suits. By passing section 5(a), Congress intended to give the private litigant as much aid in establishing a violation of the antitrust laws as was then perceived to be possible under the Constitution. Since Congress viewed this aid as a supplement to the private litigant's common law arsenal, ${ }^{28}$

(remarks of Senator Chilton); 51 CoNG. REc. 13900 (1914) (remarks of Senator White). To overcome the mutuality hurdle, several members of Congress suggested that a private litigant might be considered to be in privity with the Government. See 51 CoNG. REC. 13854 (1914) (remarks of Senator Cummins). This argument was rejected. 51 Cong. REc. 13899 (1914) (remarks of Senator Borah).

Subsequent case law has demonstrated that the mutuality requirement is not a constitutional principle. See, e.g., Blonder-Tongue Laboratories, Inc. v. University of Illinois Foundation, 402 U.S. 313 (1971).

21 Several Senators were concerned that if the Supreme Court declared a statute modeled on the House Bill unconstitutional, a prior government judgment would be given no effect in a subsequent suit. Confronted with this uncertainty, many Senators decided it would be better to give private litigants a limited amount of certain aid rather than risk having the bill declared unconstitutional. 51 CoNG. REc. 13855 (1914) (remarks of Senator Chilton); 51 Cong. Rec. 13898 (1914) (remarks of Senator Culberson); 51 Cong. REc. 13855 (1914) (remarks of Senator Cummins); 51 CoNG. REc. 13900 (1914) (remarks of Senator White).

2s 51 CoNg. Rec. 13907 (1914).

2t 51 Cong. Rec. 16276 (1914).

27 E.g., Purex Corp. v. Procter \& Gamble Co., 308 F. Supp. 584 (C.D. Cal. 1970), aff'd on other grounds, 453 F.2d 288 (9th Cir. 1971), cert. denied, 405 U.S. 1065 (1972).

28 Senator Overman, for instance, described the effect of section 5:

[w] have given to the citizen, in addition to the remedy he now has, an additional remedy, so far as the future is concerned, and we have not taken away by the statute any right which he now has.

51 CoNG. REc. 16058 (1914). See also 51 Cong. REc. 15939 (1914) (exchange between Senator Nelson and Senator Overman). This characterization was not challenged.

Additional support for the proposition that Congress did not intend the bill to be an ouster of the common law can be found in the debate over the proviso to section $5(\mathrm{a})$, which excepts consent judgments from having prima facie effect. The following exchange between Senator Norris and Senator Nelson indicates that the bill was not intended to preclude other means of utilizing private judgments:

Mr. NoRris. Notwithstanding the proviso, which says that the section shall not apply to certain cases, suppose that in all other respects it was proper to offer a judgment in evidence and there was no reason why it should not be admitted, assuming that in other respects the judgment is proper evidence, then this proviso would not exclude it, as I understand.

Mr. Nelson. No.

51 Cong. Rec. 15939 (1914). 
it is doubtful that Congress would have intended to deny the private litigant use of any subsequent beneficial common law developments. This conclusion has particular force in the case of the demise of the principle of mutuality of estoppel because it was that doctrine that compelled Congress to temper section $5(a)$ in the first place. Since section 5(a) cannot be read as ousting the common law doctrine of collateral estoppel,,$^{29}$ it is therefore necessary to examine the doctrine itself to determine its applicability in the antitrust area.

Although the above exchange dealt specifically with the consent decree exception of section $5(a)$, it is apparent that Congress did not intend to withhold from private litigants the right to use established common law doctrines.

29 In 1955 the Clayton Act was amended to give prior judgments prima facie evidence in a later suit for damages brought by the Government. These amendments provide a stronger argument for ouster of the common law. The 1955 amendments can be traced to the Supreme Court's decision in United States v. Cooper Corp., 312 U.S. 600 (1941), holding that the United States could not recover damages when injured by an antitrust violation. To fill the loophole created, Congress added section $4 \mathrm{~A}$ to the Clayton Act, 15 U.S.C. $\$ 15(\mathrm{a})$, giving the Government the right to sue for actual but not treble damages. At the same time, Congress amended section $5(a)$ to provide that a prior government judgment shall be prima facie evidence in an action brought by the Government for money damages. It is unclear, however, exactly why Congress amended section 5(a). Since the mutuality requirement would be satisfied for the second government action, the Government would presumably have been able to rely on the prior judgment as an estoppel without statutory amendment. Neither the House nor Senate Reports contain any reference to the rationale for the amendment of section $5(a)$. The sparse congressional debates are similarly uninformative on this point.

Two possible explanations seem the most plausible. It is conceivable that Congress intended to oust the common law doctrine of collateral estoppel as a compromise measure for allowing the government to sue for actual damages. The one case in which the question of the applicability of collateral estoppel arose in this context adopted this view. United States v. Grinnell Corp., 307 F. Supp. 1097 (S.D.N.Y. 1969). The only authority cited for this conclusion by the court was a statement at the hearings on the bill that the amendment of section 5(a) would place the "United States in the same category as the private litigant." See Hearings on H.R. 3658 Before Subcomm. No. 5 of the House Comm. on the Judiciary, 84th Cong., 1st Sess. 7 (1955) (remarks of Stanley N. Barnes). But placing the Government in the "same category" as the private litigant indicates only that the Government would have the same statutory remedy as the private litigant and does not, by itself, suggest that its common law rights would not survive. The more plausible explanation, given the total absence of discussion of this problem in the House and Senate Reports and Congressional debates, is that Congress simply did not consider the interplay between the statute and collateral estoppel.

Even if Congress did intend to oust the doctrine of collateral estoppel when the government sues for actual damages, it is clear that this intent would not indicate whether the original framers of the Clayton Act intended to oust the common law with respect to private litigants. It is well settled that postpassage declarations of intent cannot change the original legislative intent. See, e.g., Regional Rail Reorganization Cases, 419 U.S. 102 (1974). 


\section{Offensive Use of Collateral Estoppel and the Private Antitrust PlaintifF}

A. The Demise of the Mutuality Requirement

Collateral estoppel, like the related doctrine of res judicata, ${ }^{30}$ has dual purposes-to protect litigants from the burden of relitigating issues already determined with the same adversary or his privy and also to promote judicial economy by preventing needless litigation. ${ }^{31}$ For many years, however, the doctrine of mutuality of estoppel confined the operation of collateral estoppel by providing that neither party to a suit could use a prior judgment as an estoppel against the other unless both parties were bound by that prior judgment. ${ }^{32}$ Based on the simplistic assumption that it is unfair to allow a party to use a prior judgment decided against his current adversary to preclude relitigation of an issue when he would not have been bound by a decision in favor of his adversary, ${ }^{33}$ the mutuality requirement grants a party who has litigated and lost an opportunity to relitigate identical issues with new parties. Justice Traynor forcefully criticized this rule in Bernhard v. Bank of America: ${ }^{34}$

No satisfactory rationalization has been advanced for a requirement of mutuality. Just why a party who was not bound by a previous action should be precluded from asserting it as res judicata against a party who was bound by it is difficult to comprehend..$^{35}$

Led by Justice Traynor's assault in Bernhard, the mutuality requirement has been abandoned in many jurisdictions..$^{36}$ In

${ }^{30}$ The distinction between res judicata and collateral estoppel is a familiar one. Under the doctrine of res judicata, a judgment on the merits in a prior suit bars a second suit involving the same parties or their privies based on the same cause of action. Under the doctrine of collateral estoppel, on the other hand, the second action is upon a different cause of action and the judgment in the prior suit precludes relitigation of issues actually litigated and necessary to the outcome of the first action. 1B J. Moore, Federal Practice $\uparrow 0.405$ [1], at 622-24 (2d ed. 1974); e.g., Lawlor v. National Screen Serv. Corp., 349 U.S. 322, 326 (1955); Commissioner v. Sunnen, 333 U.S. 591, 597 (1948); Cromwell v. County of Sac, 94 U.S. 351, 352-53 (1876).

31 1B J. Moore, Federal Practice $10.405[2]$, at 631 (2d ed. 1974).

32 Bigelow v. Old Dominion Copper Co., 225 U.S. 111, 127 (1912); Restatement of JUDGMENTS $\$ 93$ (1942).

${ }^{33}$ It is a violation of due process to bind a litigant by a judgment to which he was neither a party nor a privy. Hansberry v. Lee, 311 U.S. 32, 40 (1940); cf. Pennoyer v. Neff, 95 U.S. 714 (1877).

34 19 Cal. 2d 807, 122 P.2d 892 (1942).

3519 Cal. $2 \mathrm{~d}$ at 812,122 P.2d at 895.

3* Blonder-Tongue Laboratories, Inc. v. University of Illinois Foundation, 402 U.S. 313 (1971); e.g., Federal Savings \& Loan Ins. Corp. v. Hogan, 476 F.2d 1182 (7th Cir. 1973); James Talcott, Inc. v. Allahabad Bank, Ltd., 444 F.2d 451 (5th Cir. 1971); Brown v. R.D. Werner 
Blonder-Tongue Laboratories, Inc. $v$. University of Illinois Foundation, ${ }^{37}$ the Supreme Court added momentum to this trend when it decided the relatively narrow question of whether "mutuality of estoppel is a viable rule where a patentee seeks to relitigate the validity of a patent once a federal court has declared it to be invalid." 38 But the "broader question," which formed the backdrop for the Court's decision, was "whether it is any longer tenable to afford a litigant more than one full and fair opportunity for judicial resolution of the same issue." 39

In its analysis, the Court first took note of the general trend in the state and federal courts away from the mutuality requirement and then, in this light, examined the economic consequences of requiring mutuality in patent cases. The Court noted that the "arguable misallocation of resources"40 involved whenever a party is allowed to relitigate issues that had been determined adversely in a prior action is particularly acute in patent cases because they involve "staggering expense" and length. ${ }^{41}$ The mutuality rule, the Court further noted, not only wastes the resources of the courts and litigants, but also permits the patentee to extract monopoly profits for a non-patentable invention. A defendant in an infringement action frequently finds it cheaper to pay royalties than contest the patent's validity by way of defense to the action even where the patent has been declared invalid in a prior decision..$^{42}$ Finding no persuasive reason for maintaining mutuality of estoppel in patent

Co., 428 F.2d 375 (1st Cir. 1970); Zdanok v. Glidden Co., 327 F.2d 944 (2d Cir.), cert. denied, 377 U.S. 934 (1964); Bruszewski v. United States, 181 F.2d 419 (3rd Cir.), cert. denied, 340 U.S. 865 (1950); Realty Exch. Corp. v. Phoenix Title \& Trust Co., 15 Ariz. App. 199, 487 P.2d 420 (1971); Schwartz v. Public Adm'r, 24 N.Y.2d 65, 246 N.E.2d 725, 298 N.Y.S.2d 955 (1969); Bahler v. Fletcher, 257 Ore. 1, 474 P.2d 329 (1970); Richards v. Hodson, 26 Utah 2d 113, 485 P.2d 1044 (1971); Lucas v. Velikanje, 2 Wash. App. 2d 888, 471 P.2d 103 (1970). A number of jurisdictions have recently affirmed, however, their adherence to the mutuality rule. E.g., Daigneau v. National Cash Register Co., 247 So. 2d 465 (Fla. 1971); Lukacs v. Klue \$ner, 290 N.E.2d 125 (Ind. 1972); Keith v. Schiefen-Stockham Ins. Agency, Inc., 209 Kan. 537, 498 P.2d 265 (1972); Howell v. Vito's Trucking \& Excavating Co., 386 Mich. 37, 191 N.W.2d 313 (1971); Armstrong v. Miller, 200 N.W.2d 282 (N.D. 1972); see Pomeroy v. Waitkus, 183 Colo. 344, 350, 517 P.2d 396, 399 (1974) (dictum), cited in Peffer v. Bennett, 523 F.2d 1323 (10th Cir. 1975).

37402 U.S. 313 (1971).

38 Id. at 327. In Triplett v. Lowell, 297 U.S. 638 (1936), the Court had held that a determination of patent invalidity in a prior action does not preclude a party from asserting the validity of the same patent in subsequent litigation against a different defendant.

30 Blonder-Tongue Laboratories, Inc. v. University of Illinois Foundation, 402 U.S. 313, 328 (1971).

40 Id. at 329.

1 Id. at $334,348$.

12 Id. at 338. 
litigation, the Court held that a patentee could be estopped from asserting the validity of a patent declared invalid in a prior suit if he had had "full and fair opportunity to litigate his claim in the first action." 43

\section{B. The Applicability of Blonder-Tongue in Antitrust Litigation}

The doubts expressed by the Court in Blonder-Tongue with respect to affording a patentee more than one full and fair opportunity for judicial resolution of the same issue are equally valid in the antitrust context. Antitrust litgation, like patent litigation, is characterized by long ${ }^{44}$ and expensive ${ }^{45}$ trials. These factors are at least partially responsible for the relatively poor success record of private antitrust plaintiffs ${ }^{48}$ and thus undermine the Congressional policy of encouraging private enforcement of the antitrust laws. ${ }^{47}$

${ }^{43}$ Id. at 347,350 . Although the Court did not abolish the mutuality requirement in general, it did state that "it is apparent that the uncritical acceptance of the principle of mutuality of estoppel . . . is today out of place." Id. at 350 .

1" See Posner, A Statistical Study of Antitrust Enforcement, 13 J. Law \& EcoN. 365, 374 (1970) [hereinafer cited as Posner]. See also Loevinger, Private Action-The Strongest Pillar of Antitrust, 3 ANrrTrust Bull. 167, 169 (1958) [hereinafter cited as Loevinger]; Wheeler, Antitrust Treble Damage Actions: Do They Work?, 61 CaLIF. L. REv. 1319, 1330-31 (1973) [hereinafter cited as Wheeler].

45 In 1949, Thurman Arnold stated:

[P]eople keep coming to me from all parts of the country with antitrust claims against some combination of corporations. I tell them that if they do not have $\$ 25,000$. . . they had better drop the suit. They will find themselves in the middle of suit without any evidence.

Quoted in Hearings on H.R. 3408 before the Subcomm. on Study of Monopoly Power of the House Comm. on the Judiciary, 82 d Cong., 1st Sess., No. 1, pt. 3, at 92 (1951). Such an action would undoubtedly cost more in today's dollars. See also Alioto, The Economics of a Treble Damage Claim, 32 A.B.A. Antirrust L. J. 87, 93 (1966); Wheeler, supra note 44, at 1330-31.

"Wheeler, supra note 44 , at $1330-31$. It is widely believed that the Government has a much better success ratio in antitrust cases than private plaintiffs. Alioto, supra note 45 , at 92; Arnold, The Supreme Court and the Antitrust Laws 1953-1967, 34 A.B.A. ANTrTRUST L.J. 2, 4-5 (1967); Bicks, The Department of Justice and Private Treble Damage Actions, 4 Antrtrust Bull. 5 (1959); Comment, Antitrust Enforcement by Private Parties: Analysis of Developments in the Treble Damage Suit, 61 YALE L.J. 1010 (1952). But Professor Posner has questioned the validity of such studies because they rely solely on reported cases that have gone to judgment. Professor Posner also suggests that the "spottier success of private antitrust claimants" before the Supreme Court as compared with the high degree of success achieved by the Government might be due to the fact that the Solicitor General screens cases very carefully whereas private plaintiffs are more likely to commence actions without merit. Posner, supra note 44, at 382-83. The Supreme Court, however, has shown considerable enthusiasm for the private antitrust action. See Fortner Enterprises, Inc. v. United States Steel Corp., 394 U.S. 495 (1969); Perma Life Mufflers, Inc. v. International Parts Corp., 392 U.S. 135 (1968). See also Dam, Fortner Enterprises v. United States Steel: Neither a Borrower, Nor a Lender Be, 1969 SuP. CT. REv. 1, 12, 37-38.

17 Hanover Shoe, Inc. v. United Shoe Mach. Corp., 392 U.S. 481, 494 (1968); Leh v. General Petroleum Corp., 382 U.S. 54, 59 (1965); Minnesota Mining \& Mfg. Co. v. New Jersey Wood Finishing Co., 381 U.S. 311, 317-18 (1965); Radovich v. National Football League, 352 
Collateral estoppel, by shortening private suits, would encourage private enforcement. ${ }^{48}$

The vast majority of private antitrust treble damage actions are brought after a government prosecution has successfully established the defendant's violation of the antitrust laws. ${ }^{49}$ But since a private litigant may make only limited use of the Government's judgment under section $5(\mathrm{a})$ as presently interpreted, ${ }^{50}$ the defendant, by presenting rebuttal evidence, can compel the private plaintiff to undertake full-scale discovery and to relitigate the Government's entire case. ${ }^{51}$ However, even where the defendant has had a full and fair opportunity to litigate his claim in the first action-which will typically be the case if the first action was a government prosecution for injunctive relief that went to judgment-the private litigant will have to establish that he was injured by the defendant's violation ${ }^{52}$ and that he is entitled to damages for that injury in any event. ${ }^{53}$ No sound policy requires that the private plaintiff bear the burden of reestablishing the defendant's violation..$^{54} \mathrm{By}$ depriving the private plaintiff of the full benefit of the Government's successful prosecution, the mutuality requirement functions as an economic deterrent to private antitrust enforcement. Since, as in Blonder-Tongue, private litigants may be deterred from attempting to enforce their rights, the mutuality requirement may indirectly induce the violation of the antitrust laws.

U.S. 445, 453-54 (1957); Bruce's Juices, Inv. v. American Can Co., 330 U.S. 743, 751-53 (1947).

18 The private antitrust plaintiff must also prove injury in fact and some indication of the damage suffered. See, e.g., Kestenbaum v. Falstaff Brewing Co., 514 F.2d 690 (5th Cir. 1975); Locker v. American Tobacco Co., 218 F. 447, 448 (2d Cir. 1914). In attempting to establish injury and damages the plaintiff may, to some extent, be forced to reestablish points that also bear on the issue of liability. The availability of collateral estoppel may not, therefore, significantly aid private antitrust plaintiffs in certain cases.

19 Posner, supra note 44, at 372; Wheeler, supra note 44, at 1323.

so See note 6 supra.

5s See note 6 supra; Comment, Section 5(a) of the Clayton Act and the Use of Collateral Estoppel by a Private Plaintiff in a Treble Damage Claim, 8 U. San Fran. L. Rev. 74, 80 (1973); VIRGinia Note, supra note 3, at 1352; YaLE Comment, supra note 3, at 425.

${ }_{52}$ See Comment, Proof Requirements in Anti-Trust Suits: The Obstacles to Treble Damage Recovery, 18 U. Chi. L. REv. 130, 131-32 (1950). Compare Locker v. American Tobacco Co., 218 F. 447 (2d Cir. 1914), with Bigelow v. RKO Radio Pictures, Inc., 327 U.S. 251 (1946).

${ }^{53}$ See Hoffman, Proof of Damages in Private Litigation, 36 A.B.A. ANTITRust L.J. 151 (1967); Lanzilloti, Problems of Proof of Damages in Antitrust Suits, 16 ANTrTrust Bull. 329 (1971); Comment, supra note 52.

st The existence of an antitrust conspiracy may be particularly difficult to establish. See, e.g., FTC v. Cement Institute, 333 U.S. 683, 687 (1948) (100,000 page record compiled in three years of FTC hearings). 


\section{The Offensive-Defensive Distinction}

Even though many of the reasons relied on by the Court in Blonder-Tongue apply with equal force when a private litigant attempts to make use of a successful government action for injunctive relief, there is one major difference between the two situations-the private antitrust litigant is seeking to use collateral estoppel offensively whereas the Blonder-Tongue situation involves defensive use. ${ }^{55}$ Several recent cases have followed Blonder-Tongue by sanctioning the defensive use of collateral estoppel in antitrust litiga$\operatorname{tion}^{58}$ and several more have suggested that offensive use of collateral estoppel may be available to injured parties following a private antitrust suit. ${ }^{57}$ But because of the present interpretation of section $5(a){ }^{58}$ no cases have allowed offensive use of collateral estoppel when a private plaintiff follows a successful government judgment. ${ }^{59}$

${ }^{35}$ Offensive use of collateral estoppel occurs when the plaintiff seeks to estop the defendant from litigating an issue the defendant has previously litigated unsuccessfully in an action with another party. Defensive use occurs when a defendant seeks to estop the plaintiff from asserting a claim the plaintiff has previously litigated and lost against another defendant.

st See, e.g., Poster Exch., Inc. v. National Screen Serv. Corp., 517 F.2d 117 (5th Cir. 1975); Raitport v. Commercial Banks Loc. Within This Dist., 391 F. Supp. 584 (S.D.N.Y. 1975).

${ }^{57}$ J.M. Woodhull, Inc. v. Addressograph Multigraph Corp., 62 F.R.D. 58, 61 (S.D. Ohio 1974); Bill Minielli Cement Contracting, Inc. v. Richter Concrete, 62 F.R.D. 381, 386 (S.D. Ohio 1973); Wall Prod. Co. v. National Gypsum Co., Civil No. 46414-A (N.D. Cal. 1971) (offensive collateral estoppel is available), noted in Comment, Section 5(a) of the Clayton Act and the Use of Collateral Estoppel by a Private Plaintiff in a Treble Damage Action, 8 U. SAN Fran. L. Rev. 74, 88 (1973); see id. at 87-88. For a discussion of the possibility of dispensing with the notice requirement in class actions under FED. R. Clv. P. 23 and thereby allowing offensive use of collateral estoppel in the class action context, see Dam, Class Action Notice-Who Needs It? 1974 Sup. CT. REv. 97.

ss See note 2 supra. It seems odd to allow offensive use of collateral estoppel after a private antitrust suit but not after a government suit when section 5 (a) was enacted expressly to aid private litigants following government suits. See text and notes at notes 8-29 supra.

3o In other contexts, courts have recently generally permitted offensive use of collateral estoppel. E.g., Zdanok v. Glidden Co., 327 F.2d 944 (2d Cir.), cert. denied, 377 U.S. 934 (1964); Maryland v. Capital Airlines, Inc., 267 F. Supp. 298 (D. Md. 1967); United States v. United Airlines, Inc., 216 F. Supp. 709 (E.D. Wash. \& D. Nev. 1962), aff'd, 335 F.2d 379 (9th Cir.), cert. dismissed, 379 U.S. 951 (1964); Vanguard Recording Soc'y, Inc. v. Fantasy Records, Inc., 24 Cal. App. 3d 410, 100 Cal. Rptr. 826 (1972); Thill v. Modern Erecting Co., 284 Minn. 508, 170 N.W.2d 865 (1969); Desmond v. Kramer, 96 N.J. Super. 960, 213 A.2d 26 (1967); B.R. DeWitt, Inc. v. Hall, 19 N.Y.2d 141, 225 N.E.2d 195, 278 N.Y.S.2d 596 (1967); Bahler v. Fletcher, 257 Ore. 1, 474 P.2d 329 (1970).

RESTATEMENT (SECOND) OF JUDGmENTS (Tent. Draft No. 2, 1975) states that there is "no intrinsic difference" between offensive and defensive use. See id. at $\$ 88$, Reporter's Note at 99. But see, e.g., Berner v. British Commonwealth Pac. Airlines, Ltd., 346 F.2d 532 (2d Cir. 1965); Spettigue v. Mahoney, 8 Ariz. App. 281, 445 P.2d 557 (1968); Nevarov v. Caldwell, 161 Cal. App. 2d 762, 327 P.2d 111 (1958); Albernaz v. City of Fall River, 346 Mass. 336, 191 N.E.2d 771 (1963). 
Since Congress did not necessarily intend to foreclose collateral estoppel in this situation, this comment will now examine the three principal arguments that have been offered for limiting the use of offensive collateral estoppel to determine if they provide a sufficient rationale for refusing to grant a government antitrust judgment, in particular a government injunction, conclusive weight in a subsequent private suit.

1. The Multiple Claimant Anomaly. The most familiar argument for not applying collateral estoppel offensively against a defendant is what Professor Brainerd Currie termed the "multiple claimant anomaly." ${ }_{60}$ In Professor Currie's oft-cited illustration, a railroad collision injures fifty passengers, all of whom bring separate actions against the railroad. The railroad prevails in the first twenty-five actions, ${ }^{61}$ but in suit twenty-six, plaintiff wins. On the strength of this example, Professor Currie contends that offensive estoppel should not be allowed, because if it is allowed plaintiffs twenty-seven through fifty will automatically recover from the railroad simply by proving damages. ${ }^{62}$

Although the fears of injustice expressed by Professor Currie have substance in general, the scenario he postulated is unlikely to occur where a private antitrust plaintiff brings an action after a prior successful government suit. Professor Currie's views were based on the suspicion that the verdict for plaintiff in the twentysixth suit was probably an "aberration." ${ }^{63}$ While the possibility of an incorrect and therefore aberrational verdict undoubtedly always exists, the vigor with which antitrust charges are usually contested ${ }^{64}$ assures that "decisions in such suits represent the closest approximation to objective certainty possible in litigation." ${ }^{65}$ Moreover, it

Various commentators have expressed reservations regarding the desirability of offensive estoppel. B. Currie, Mutuality of Estoppel: Limits of the Bernhard Doctrine, 9 STAN. L. REv. 281 (1957) [hereinafter cited as Currie]; Semmel, Collateral Estoppel, Mutuality and Joinder of Parties, 68 Colum. L. Rev. 1457 (1968) [hereinafter cited as Semmel]; Note, The Impacts of Defensive and Offensive Assertion of Collateral Estoppel by a Nonparty, 35 GEo. WaSH. L. Rev, 1010 (1967) [hereinafter cited as Impacts]. Professor Currie later tempered his reservations. B. Currie, Civil Procedure: The Tempest Brews, 53 Calrf. L. Rev. 25 (1965).

${ }^{80}$ Currie, supra note 59 , at 285-89.

o1 No matter how many suits a defendant wins, a plaintiff not a party or in privity with a party to one of those suits cannot be barred from asserting his own claim. See note 28 supra.

${ }^{62}$ Currie, supra note 59, at 304.

${ }^{83}$ Id. at 289.

st See note 44 supra. For an example, though perhaps not typical, of how vigorously antitrust proceedings are litigated, see United States v. Paramount Pictures, Inc., 66 F. Supp. 881 (S.D.N.Y. 1949), rev'd in part, 334 U.S. 131 (1948), on remand, 85 F. Supp. 881 (S.D.N.Y. 1949), aff'd per curiam sub nom. Loew's, Inc. v. United States, 339 U.S. 974 (1950). This suit was contested on the merits for thirteen years.

os Hardy, supra note 10, at 48. 
is unlikely that an antitrust defendant would successfully defend a series of related suits before losing a single, but fatal decision. The enormous costs of private antitrust litigation would probably deter potential plaintiffs from following unsuccessful predecessors. And if a plaintiff were to attempt to establish a claim that a prior plaintiff could not, it would probably be because he viewed the prior judgment as the aberrant decision.

In reality, the situation where offensive estoppel is most likely to be asserted is where the Government brings the first suit against the defendant and is successful. ${ }^{66}$ Since the defendant has lost the first suit, application of offensive collateral estoppel will not produce inconsistent results. If doubts regarding the correctness of the first judgment are sufficient to reject estoppel here, then it is hard to see why a party should ever be able to assert collateral estoppel or res judicata; an incorrect judgment is an ever-present danger. ${ }^{67}$ Professor Currie's fears thus prove too much.

It is possible, however, that offensive estoppel could generate anomalous results if the successful government suit that was the basis for estoppel were preceded by one or more unsuccessful private actions. If a private plaintiff brought an action following the government judgment, the trial court would have to decide whether to estop the defendant from relitigating the issues that were determined in the government suit. Under Professor Currie's analysis, the existence of prior inconsistent judgments would cast doubt on the correctness of the government judgment and therefore it should not be the basis for an estoppel in a subsequent suit. ${ }^{68}$ Recent cases interpreting Blonder-Tongue, however, have emphasized that the application of collateral estoppel does not depend on whether the prior finding was "correct" but rather on whether the plaintiff had "a full and fair opportunity to litigate" in the prior suit." If the

"See text and note at note 48 supra.

" As Professor James has stated:

[C]ollateral estoppel like any other aspect of res judicata always involves the possibility of perpetuating error . . . . But this possibility is a price society has decided to pay . . . for the benefits that flow from finality.

James, Consent Judgments as Collateral Estoppel, 108 U. PA. L. REv. 173, 187 (1959).

" Currie, supra note 59, at 304.

" See Blumcraft of Pittsburgh v. Kawneer Co., 482 F.2d 542 (5th Cir. 1973); CarterWallace, Inc. v. United States, 496 F.2d 535 (Ct. Cl. 1974). Although these cases involved defensive estoppel, the courts' reasoning was equally applicable to offensive use. But cf. REsTatement (SECOND) OF JudGMENTS (Tent. Draft No. 2) § 88(4), providing that estoppel can be denied where the determination relied upon as preclusive was itself inconsistent with another determination of the same issue. But one of the two cases relied upon in the commentary (see Reporter's Note at 101) is Blumcraft, which stands for precisely the opposite proposition. The other case cited in support of its position, Fink v. Coates, 323 F. Supp. 988 
defendant had had a "full and fair opportunity to litigate" in the government suit, then, under current principles of estoppel, the existence of prior inconsistent judgments should not preclude estoppel, Professor Currie's fears notwithstanding.

2. Adverse Impact on Consolidation. Defensive use of collateral estoppel will generally prevent a plaintiff who has tried his claim unsuccessfully from relitigating the identical issues by "switching adversaries." Defensive estoppel therefore promotes judicial economy by removing any incentive that plaintiffs might have not to join all potential defendants in the first action. ${ }^{71}$ It has been argued, however, that offensive estoppel will increase rather than decrease overall litigation ${ }^{72}$ because potential plaintiffs will not intervene in on-going suits, realizing that they have everything to gain and nothing to lose by staying out of the first action. ${ }^{73}$

The preferable way to treat this problem in general is not to deny all use of offensive estoppel but to grant discretion to the trial courts to deny the benefits of estoppel to a plaintiff who reasonably could have joined in the first action..$^{74}$ But such a drastic solution is not necessary when private antitrust plaintiffs adopt a wait-and-see

(S.D.N.Y. 1971), does not deal with inconsistent prior verdicts. Nevertheless, some courts have hinted that they would not allow collateral estoppel to be applied offensively if it would lead to inconsistent results. See, e.g., Zdanok v. Glidden Co., 327 F.2d 944, 955-56 (2d Cir. 1964).

70 Bernhard v. Bank of America, 19 Cal. 2d 807, 813, 122 P.2d 892, 895 (1942).

7 In Bruszewski v. United States, 181 F.2d 419, 421 n.2 (3d Cir.), cert. denied, 340 U.S. 865 (1950), the court stated, "While the claimant was not obliged thus to consolidate his suits, no canon of fairness requires that he be given the special advantage of twice trying the same issue where he did not elect to join them." See Impacts, supra note 59, at 1025.

72 Semmel, supra note 59, at 1473-79; Impacts, supra note 59, at 1032-36.

73 If the plaintiff wins the first action, then other claimants can use that judgment as collateral estoppel against the same defendant in subsequent actions. But if the plaintiff loses the first action, other claimants will not be barred unless they were parties or privies to the action. See note 33 supra. Therefore, the prospective plaintiff is likely to adopt a "wait-andsee" attitude. See Nevarov v. Caldwell, 161 Cal. App. 2d 762, 767-68, 327 P.2d 111, 115 (1958); Reardon v. Allen, 88 N.J. Super. 560, 571-72, 213 A.2d 26, 32 (1965).

7 The RESTATEMENT (SECOND) OF JudgmeNTS, supra note $59, \S 88$ (3), provides that offensive use of collateral estoppel may be denied when the party asserting it could have joined in the original action. However, the Restatement specifies that estoppel should be denied only when the circumstances suggest that the plaintiff wished to avail himself of the benefits of a favorable outcome without incurring the risk of an unfavorable one. The Restatement makes clear, moreover, that the plaintiff retains the "normally available option" of prosecuting his own claim without the impediment of joining with others "whose situation does not substantially coincide with his own." See id. $\S 88$ (3), comment e. Since the private antitrust plaintiff will be attempting to prove a different cause of action than the Government, and will be seeking different relief (treble damages), see text and note at note 49 supra, it is unlikely that a failure to attempt to intervene in a government suit would preclude the private plaintiff from relying on the government judgment. Moreover, it is probable that the private plaintiff would not be permitted to intervene in a government suit. See text and note at note 77 infra. 
attitude with respect to government prosecutions because Congress evidently assumed that they would do so. The prima facie evidence provision of section 5(a) was an attempt on the part of Congress to encourage plaintiffs to follow and take advantage of prior government actions, ${ }^{75}$ as was the provision of section $5(\mathrm{~b})$ of the Clayton Act $^{78}$ tolling the statute of limitations when the Government files suit. Moreover, since a private plaintiff would probably not be permitted to intervene in a government prosecution, ${ }^{77}$ there is no reason to penalize him for failing to do so.

3. The Unfavorable Liability-Favorable Damages Dilemma. A third argument against offensive estoppel is that it may work an unfairness on a defendant who lost the first action but who had only minimal damages assessed against him. ${ }^{78}$ If the defendant decided not to appeal because the damages were so low, he will be unable to deny his liability if later sued by other plaintiffs on the same claim..$^{79}$ To insure himself against potentially staggering liability, a defendant might be forced to file a protective appeal even though he considered the results of the first suit otherwise satisfactory.

In fact, the possibility of offensive estoppel will rarely force an antitrust defendant to file a protective appeal. The antitrust defendant already has strong incentives to appeal an adverse judgment.

is See text and notes at notes 10-11 supra.

7" Whenever any criminal or civil proceeding is instituted by the United States to prevent, restrain, or punish violations of any antitrust laws . . . the running of the statute of limitations in respect of every private right of action . . . shall be suspended during the pendency thereof and for one year thereafter . . . .

15 U.S.C. \& 16(b) (1970).

77 In SEC v. Everest Management Corp., 475 F.2d 1236 (2d Cir. 1972), the court refused to allow victims of a securities fraud to intervene in an SEC enforcement action. The court believed that private intervention would place too heavy a burden on the government enforcement machinery by injecting additional issues into already complicated lawsuits and would also hamper government attempts to obtain consent decrees. It is probable that a private antitrust plaintiff would meet similar resistance if he attempted to intervene. $C f$. Trbovich v. United Mine Workers, 404 U.S. 528 (1972); Sam Fox Publishing Co. v. United States, 366 U.S. 683 (1961). But cf. Loevinger, supra note 44 , who suggests that private antitrust plaintiffs should be allowed to intervene in government proceedings.

${ }^{78}$ See Berner v. British Commonwealth Pac. Airlines, 346 F.2d 532 (2d Cir. 1965), cert. denied, 382 U.S. 983 (1966). Plaintiff sought $\$ 500,000$ damages for injuries sustained in a plane crash. Defendant chose not to appeal a verdict of $\$ 35,000$ and the judgment was not given collateral estoppel effect in a later action against a different plaintiff on a claim of over $\$ 7,000,000$.

7D Defendants will be particularly likely not to appeal if future suits were not foreseeable. See Evergreens v. Nunan, 141 F.2d 927, 929 (2d Cir. 1944). Although it may be argued that it would be unjust to permit offensive estoppel to be asserted against a defendant who could not reasonably foresee the likelihood of future suits in time to appeal, given the large percentage of private antitrust suits following successful government judgments, see text at note 48 supra, few defendants in government actions could credibly argue that private treble damage suits were unforeseeable. 
A defendant might appeal a small antitrust judgment or a government-obtained injunction simply to avoid adverse publicity or stigma. More important, the prima facie effect already accorded to adverse findings under section 5(a) in subsequent private treble damage suits is in itself a significant incentive. Finally, even if the possibility of collateral estoppel does tip the balance in favor of an appeal in a few cases, it still seems clear that far more unnecessary litigation would result if offensive estoppel were not permitted at all in antitrust cases. Since antitrust defendants will appeal most adverse judgments in any event, the possibility of a few unwarranted appeals is not a sufficient reasion for foreclosing the use of offensive estoppel; defendants should not, moreover, be able to control the weight to be given to an adverse judgment in a subsequent suit by choosing not to appeal. ${ }^{80}$ Thus this argument, like the two preceding ones, fails to offer a convincing rationale for refusing to permit a private plaintiff to introduce a prior government judgment against the same defendant as conclusive evidence of the defendant's antitrust violation.

\section{Particular Applications of Collateral Estoppel When a Private Plaintiff Follows a Government JUDGMENT}

Even though a judgment rendered in a successful government prosecution for injunctive relief should have collateral estoppel effect in a subsequent private action, it does not necessarily follow that all types of government orders should be granted conclusive effect. This comment will now examine the applicability of collateral estoppel where the prior judgment stemmed from either a Federal Trade Commission order, a consent judgment or a criminal prosecution.

\section{A. FTC Orders}

Section 11 of the Clayton Act ${ }^{81}$ empowers the FTC to enforce the Clayton Act concurrently with the Justice Department. ${ }^{82} \mathrm{Al}$ though FTC enforcement orders are admissible as prima facie evi-

so Cf. Blumcraft of Pittsburgh v. Kawneer Co., 482 F.2d 542 (5th Cir. 1973).

81 Clayton Act $\S 11,15$ U.S.C. $\S 21$ (1970), gives the FTC the power to enforce $\S \S 2,3,7$, and 8 of the Act.

${ }^{82}$ See generally Posner, supra note 44; Rockefeller \& Ward, Antitrust Enforcement By the FTC and the Department of Justice: A Primer for Small Business, 22 Dick. L. REv. 251 (1962). 
dence under section 5(a) ${ }^{83}$ the question of whether a FTC order can have collateral estoppel effect in a subsequent civil action has been dealt with only in Purex Corp. $v$. Procter \& Gamble Co. ${ }^{84}$ The Purex court held that a prior FTC order could not be asserted as collateral estoppel, but it based its decision on the erroneous assumption that section 5(a) preempts the doctrine of collateral estoppel. ${ }^{85}$ The question of the weight to be accorded a FTC order in a subsequent private suit therefore remains open.

In United States v. Utah Construction \& Mining Co. ${ }^{86}$ the Supreme Court put to rest any doubts that administrative agency determinations could not have res judicata or collateral estoppel effect in subsequent legal actions. ${ }^{87}$ The Court stated that granting conclusive effect to an agency decision is proper when the agency "is acting in a judicial capacity and resolves disputed issues of fact properly before it which the parties have had an adequate opportu-

${ }^{83}$ See New Jersey Wood Finishing Co. v. Minnesota Mining \& Mfg. Co., 332 F.2d 346 (3d Cir. 1964), aff'd, 381 U.S. 311 (1965). The court reasoned that an FTC proceeding is in reality a suit by the United States and that by virtue of the Finality Act of 1959, 21 U.S.C. $\S$ 21(g), an FTC order, whether appealed or not, is a "final judgment or decree" rendered in a "suit or proceeding in equity brought by or on behalf of the United States" within the meaning of section 5(a). The court distinguished such cases as Proper v. John Bene \& Sons, 295 F. 729 (E.D.N.Y. 1923) and Brunswick-Balke-Collender Co. v. American Bowling \& Billiard Corp., 150 F.2d 69 (2d Cir. 1945), which had held that FTC orders were not "final" and therefore inadmissible, on the ground that these cases were decided before the Finality Act was enacted and were therefore no longer good law.

On appeal, the Supreme Court held that an FTC proceeding tolls the statute of limitations under section 5(b) but expressed "no opinion" on whether an FTC order is admissible under section 5(a). Minnesota Mining \& Mfg. Co. v. New Jersey Wood Finishing Co., 381 U.S. 311 (1965). Subsequent lower court decisions, however, have uniformly held that FTC orders are admissible under section 5(a). Purex Corp. v. Procter \& Gamble Co., 453 F.2d 288 (9th Cir. 1971), cert. denied, 405 U.S. 1065 (1972); Farmington Dowel Prods. Co. v. Forster Mfg. Co., 421 F.2d 61 (1st Cir. 1970).

FTC orders pursuant to section 5 of the FTC Act, however, are generally inadmissible under section 5(a). In re Antibiotic Antitrust Actions, 333 F. Supp. 317 (S.D.N.Y. 1971); Y \& Y Popcorn Supply Co. v. ABC Vending Corp., 263 F. Supp. 709 (E.D. Pa. 1967). Section 5, which empowers the FTC to proscribe unfair competition and deceptive acts in commerce, is by statutory definition not an antitrust law. 15 U.S.C. $\S \S 12,44$ (1970); see, e.g., Pep Boys-Manny, Moe \& Jack, Inc. v. FTC, 122 F.2d 158 (3d Cir. 1941). If the FTC decree included $a$ finding that the defendant not only engaged in unfair methods of competition but also violated an antitrust law, the decree can be admitted as prima facie evidence in a subsequent treble damage action. See, e.g., Y \& Y Popcorn Supply Co. v. ABC Vending Corp., 263 F. Supp. 709, 712-13 (E.D. Pa. 1967).

s 308 F. Supp. 584 (C.D. Cal. 1970), aff'd on other grounds, 453 F.2d 288 (9th Cir. 1971), cert. denied, 405 U.S. 1065 (1972).

ss See text and notes at notes 8-29 supra.

st 384 U.S. 394 (1966).

87 Before this decision, there were inconsistent lower court decisions on this question. Compare, e.g., Churchill Tabernacle v. FCC, 160 F.2d 244 (D.C. Cir. 1947), with Aiken v. Cogswell, 201 F.2d 705 (D.C. Cir. 1952). 
nity to litigate . . . ."88 Under this test, a FTC order should be given collateral estoppel effect in a subsequent private action. ${ }^{89}$

Examination of the FTC Rules of Practice ${ }^{90}$ indicates that a FTC antitrust enforcement proceeding is much like a judicial proceeding and offers litigants a full opportunity to be heard before decision. ${ }^{91}$ The FTC commences the proceeding by filing a complaint containing notice of the alleged violations ${ }^{92}$ and the desired relief. ${ }^{93}$ After the respondent is given a chance to answer the complaint, ${ }^{94}$ a pre-trial conference is available on the motion of either party or the administrative law judge.$^{95}$ Each party has broad discovery rights, ${ }^{96}$ may present evidence, cross-examine witnesses, make objections, and otherwise has "all other rights essential to a fair hearing," ${ }^{97}$ including a presumption of innocence. ${ }^{98}$ After the

384 U.S. 394, 422 (1966). The Court did not define further the elements of the standard it announced.

89 The Utah Construction standard has been applied to accord collateral estoppel effect to other administrative agency determinations. See generally Groom v. Kawasaki Motors Corp., USA, 344 F. Supp. 1000 (W.D. Okla. 1972). National Labor Relations Board unfair labor practice determinations, for example, pursuant to $\S 8(\mathrm{~b})(4)$ of the Labor-Management Relations Act, 29 U.S.C. $\& 158(b)(4)$ (1970), have been held to estop the respondent from denying the unfair labor practice in a suit for damages brought under $\S 303$ of the Act, 29 U.S.C. \$ 187 (1970). E.g., H.L. Robertson \& Assoc. v. Plumbers Local 519, 429 F.2d 520 (5th Cir. 1970); Painters Dist. Council 38 v. Edgewood Contracting Co., 416 F.2d 1081 (5th Cir. 1969); Texaco, Inc. v. Plasterers Local 685, 343 F. Supp. 267 (W.D. La. 1972), aff'd per curiam, 472 F.2d 594 (5th Cir.), cert. denied, 414 U.S. 906 (1973). But see Riverton Coal Co. v. United Mine Workers, 453 F.2d 1035 (6th Cir. 1972).

so 16 C.F.R. §§ 3.1-3.72 (1975).

"I In Farmington Dowel Prods. Co. v. Forster Mfg. Co., 421 F.2d 61, 73-74 (1st Cir. 1970), the court noted that an FTC proceeding includes every major protection provided in the Federal Rules of Civil Procedure.

12 16 C.F.R. \& 311(b)(2) (1975); cf. FED. R. Crv. P. 8(a)(2). If a respondent cannot frame a responsive answer, he may move for a more definite statement. 16 C.F.R. $\S 3.11$ (c) (1975); cf. FED. R. Crv. P. 12(e).

is 16 C.F.R. § 3.11(b)(3) (1975); cf. FeD. R. Crv. P. 8(a)(3).

" 16 C.F.R. \$ 3.12(b)(1)(ii) (1975); cf. FED. R. Crv. P. 8(b). A respondent has thirty days to file an answer after having been served with a complaint. 16 C.F.R. $\$ 3.12(\mathrm{a})(1975)$; cf. FED. R. Crv. P. 12(a).

16 C.F.R. $\S 3.12$ (b)(1)(i) (1975); cf. FED. R. Crv. P. 8(c). Amendments to the pleadings are permitted, either by leave of the administrative law judge, 16 C.F.R. $\S 3.15(a)(1)(1975)$, or by conformance to the evidence. 16 C.F.R. $\S 3.15(a)(2)$ (1975); cf. FED. R. Crv. P. 15(b). If events occur subsequent to the pleadings which are relevant to issues involved, the administrative law judge may permit service of supplemental pleadings. 16 C.F.R. $\S 3.15$ (b) (1975); cf. FED. R. Crv. P. 15(d).

is 16 C.F.R. § 3.21(a), (d) (1975); cf. FED. R. CIv. P. 16.

"Parties may request admissions, 16 C.F.R. $§ 3.31$ (1975); cf. FED. R. Crv. P. 36; conduct depositions, 16 C.F.R. § 3.33 (1975); cf. FED. R. CIv. P. 30, 31; and compel the production of documents, 16 C.F.R. $\$ 3.34$ (1975); cf. FED. R. Crv. P. 34. Failure to comply with discovery orders is punishable by a variety of sanctions. 16 C.F.R. § 3.38 (1975); cf. FED. R. CIv. P. 37.

s7 16 C.F.R. $\S 3.41(\mathrm{c})(1975)$.

${ }^{98} I d . \$ 3.43(\mathrm{a})$. 
administrative law judge issues an order ${ }^{99}$ based on a written opinion, ${ }^{100}$ either party may appeal the administrative law judge's decision to the Commission; ${ }^{101}$ respondents who lose before the Commission have a further but limited right to review by the court of appeals. ${ }^{102}$ Since the FTC proceeding is substantially similar to a judicial proceeding, ${ }^{103}$ and the respondent is given an adequate, if not full opportunity to be heard, it would not be improper for the courts to grant conclusive effect to a finding in a FTC proceeding that the respondent violated the antitrust laws. Such a rule, moreover, would be compatible with the current practice of allowing FTC orders to be used for collateral estoppel purposes in later suits between the same parties. ${ }^{104}$

\section{B. Consent Decrees}

Even if consent decrees ${ }^{105}$ were not exempted from having prima

"Id. § 3.51(b).

${ }^{100} \mathrm{Id}$. The opinion must include conclusions regarding all material issues of fact, law or opinion, and the reasons for the conclusions.

10I Id. § 3.52(a).

102 Clayton Act $\S 11$ (c), 38 Stat. 734 (1914), as amended, 15 U.S.C. $\S 21(c)$ (1970). The court of appeals is to uphold Commision findings that are supported by substantial evidence.

${ }^{103}$ There are only two material differences between an FTC proceeding and a civil proceeding before a court. First, unlike the federal courts, the FTC contains both an adjudicative and a prosecutorial branch. However, the FTC operates under the internal separation of functions plan of the Administrative Procedure Act, 15 U.S.C. $\$ 21$ (c) (1970), and its Rules of Practice attempt to minimize the danger of possible abuses by providing that investigators and prosecutors never serve as judges in adjudicatory hearings. 16 C.F.R. $\$ 3.42$ (a) (1975). Moreover, the Rules forbid hearing officers from working under the supervision of any officer involved in a prosecutorial or investigative capacity. 16 C.F.R. $\$ 3.42(f)$ (1975); cf. Marcello v. Bonds, 349 U.S. 302 (1955); United States ex rel. Accardi v. Shaughnessy, 347 U.S. 260 (1954).

The second, and more significant difference, is that hearsay evidence may be admissible in an FTC proceeding. 16 C.F.R. $\$ 3.43(\mathrm{~b})(1975)$. Since an FTC proceeding does not involve a jury, this difference is not that substantial. A hearing examiner experienced in the law should be able to weigh hearsay evidence correctly. See K. DAvis, ADministrative Law Treatise $\$ \S 14.00,-.01$ (Supp. 1975); United States v. United Shoe Mach. Corp., 89 F. Supp. 349, 355 (D. Mass. 1950). See also Matteoni, An Antitrust Argument: Whether a Federal Trade Commission Order Is Within the Ambit of the Clayton Act's Section 5, 40 Notre Dame LAw. 158, 166 (1965); 15 VILL. L. REv. 739, 745 (1970). Finally, the respondent in an FTC proceeding is protected against unwarranted reliance on hearsay testimony by his right to appellate review. See, e.g., Consolidated Edison Co. v. NLRB, 305 U.S. 197, 229-30 (1938) (Hughes, C.J.).

104 United States v. Williard Tablet Co., 141 F.2d 141 (7th Cir. 1944); United States v. Hindman, 179 F. Supp. 926 (D.N.J. 1960). As one court said about these decisions: "Necessarily implicit in these decisions is the proposition that a Final Commission order is qualitatively comparable to a court judgment." Farmington Dowell Prods. Co. v. Forster Mfg. Co., 421 F.2d 61, 76 n.38 (1st Cir. 1970).

105 See generally Dabney, Consent Decrees Without Consent, 63 CoLum. L. REv. 1053 (1963); Flynn, Consent Decrees in Antitrust Enforcement: Some Thoughts and Proposals, 53 
facie effect under section 5(a), the parties in a government suit would have strong incentives to settle prior to judgment. ${ }^{106} \mathrm{By}$ joining in a consent decree, the Government achieves its primary objective of ceasing the defendant's antitrust violation and in the process frees its limited prosecutorial resources for use elsewhere. The advantage to the defendant is also obvious: a long, expensive and potentially embarrassing trial can be avoided, generally without an admission of guilt. ${ }^{107}$ By excluding consent decrees from section 5(a), ${ }^{108}$ Congress hoped to further encourage such economical, outof-court settlements by providing defendants with an additional incentive to capitulate voluntarily. ${ }^{109}$

Even though Congress clearly intended to deny consent judgments prima facie effect, the legislative history of the Clayton Act suggests that consent judgments could be admissible as evidence in subsequent suits for certain purposes. ${ }^{110}$ Thus, as in the case of government judgments in general, Congress did not necessarily intend to preclude the courts from according consent judgments collateral estoppel effect. The Supreme Court, however, has followed general principles of common law ${ }^{111}$ in antitrust cases and denied

IowA L. REv. 983 (1968); McHenry, The Asphalt Clause-A Trap for the Unwary, 36 N.Y.U.L. REv. 1114 (1961); Sullivan, Enforcement of Government Antitrust Decrees by Private Parties: Third Party Beneficiary Rights and Intervenor Status, 123 U. PA. L. Rev, 822 (1975); Comment, Consent Decrees and the Private Action: An Antitrust Dilemma, 53 CaLIF. L. REv. 627 (1965); VIRGINIA NoTe, supra note 3; Comment, Section 5 of the Clayton Act and Entry of Consent Decree Without Government Consent, 1963 Wis. L. REv. 459.

${ }^{108}$ Approximately 80 percent of all civil antitrust suits in the Government's favor are consent judgments. Posner, supra note 44, at 374; Comment, Private Participation in Department of Justice Antitrust Proceedings, 39 U. CHI. L. REv. 143 (1971).

${ }_{107}$ Dabney, supra note 105, at 1060; Flynn, supra note 105, at 1003.

${ }^{103}$ See text of statute at note 3 supra.

10051 Cong. Rec. 15824 (1914) (remarks of Senator Lewis); 51 Cong. Rec. 16276 (1914) (remarks of Rep. Webb). The consent decree exemption was sharply attacked by other senators. 51 Cong. Rec. 15821 (1914) (remarks of Senator Reed).

"10 See the exchange between Senator Nelson and Senator Clapp, supra note 28. It was generally agreed, however, that private litigants would have been unable to make any use of a consent judgment under then existing law. 51 CoNG. REc. 15824 (1914) (remarks of Senator Reed); 51 Cong. ReC. 15939 (1914) (remarks of Senator Nelson).

iI IB J. Moore, Federal Practice fo 0.444[3], at 4018 (2d ed. 1974); United States v. International Bldg. Co., 345 U.S. 502 (1953); Purvis v. Great Falls Bldg. \& Constr. Trades Council, 266 F. Supp. 661 (D. Mont. 1967). But see Ansara v. Regan, 276 Mass. 586, 177 N.E. 671 (1931); Biggio v. Magee, 272 Mass. 185, 172 N.E. 336 (1930); Kelleher v. Lozzi, 7 N.J. 17, 80 A.2d 196 (1951); Public Serv. Elec. \& Gas Co. v. Waldroup, 38 N.J. Super. 419, 119 A.2d 172 (App. Div. 1955). The commentators are in unanimous agreement that consent judgments should not be accorded collateral estoppel effect. See, e.g., 1B J. Moore, FEDERAL Practice If 0.444[3], at 4024 (2d ed. 1974); James, Consent Judgments as Collateral Estoppel, 108 U. PA. L. Rev. 173, 175 (1959); Polaski, Collateral Estoppel-Effects of Prior Litigation, 39 Iowa L. REv. 217, 226 (1954).

A consent judgment, even if not entitled to collateral estoppel effect in a later suit on a 
the use of a consent judgment from a private antitrust suit as an estoppel in a subsequent suit on the grounds that the consent decree was not adjudication on the merits. ${ }^{112}$ This result seems correct and should be followed where the consent decree is from a government suit. ${ }^{113}$ Recognition of collateral estoppel in this situation would not only violate the parties' understanding of the consent order, it would also frustrate, by eliminating one of the defendant's incentives to capitulate, the congressional policy of conserving the Government's prosecutorial resources.

Since the private antitrust plaintiff should and probably will not be able to assert a government consent decree as collateral estoppel in a later suit, the remaining question is whether the defendant can control the weight to be given a government judgment by "unilaterally" consenting to the entry of a consent decree. ${ }^{114}$ If a defendant can do so he can, in government injunctive actions, voluntarily agree to cease his behavior without paying any damages or increasing the likelihood of having to do so in the future. ${ }^{115} \mathrm{If}$, on the other hand, the Government can withhold its consent from the entry of a consent judgment, it can force the defendant to undergo a trial to which section 5(a) will apply or it can condition its consent on the defendant admitting that it has violated the antitrust laws. ${ }^{16}$

different cause of action, is res judicata between the parties in a later suit upon the same cause of action. E.g., Lawlor v. National Screen Serv. Corp., 349 U.S. 322, 327 (1955); United States v. International Bldg. Co., 345 U.S. 502, 506 (1953).

112 Lawlor v. National Screen Serv. Corp., 349 U.S. 322, 327 (1955).

${ }^{113}$ Although it could be argued that the parties to a consent decree intend the decree to operate as an estoppel as between them in subsequent suits, see James, supra note 111, at 175 , this intention is unlikely in antitrust cases. Since one of the prime incentives an antitrust defendant has for negotiating a consent decree with the Government is that the judgment will not be prima facie evidence in a later treble damage suit (see text at note 107 supra), it cannot be argued that the defendant intended to estop himself from denying he had violated the antitrust laws if later sued again by the Government.

114 A consent decree has traditionally meant a court order based on a bilateral agreement between the parties. See, e.g., United States v. Swift \& Co., 286 U.S. 106 (1932); Swift \& Co. v. United States, 276 U.S. 311 (1928); United States v. Hartford-Empire Co., 1 F.R.D. 424 (N.D. Ohio 1940). But there is some support for the view that in antitrust cases, only the unilateral consent of the defendant is needed. " '[C]onsent' does not necessarily refer to or indicate bilateral agreement . . . ." Twin Ports Oil Co. v. Pure Oil Co., 26 F. Supp. 366, 371 (D. Minn. 1939), aff'd on other grounds, 119 F.2d 747 (8th Cir.), cert. denied, 314 U.S. 644 (1941).

13 Somewhat analogously, defendants in actions for injunctive relief are generally unable to moot the case by voluntarily ceasing the challenged behavior. See Comment, Substitution Under Federal Rule of Civil Procedure 25(d): Mootness and Related Problems, 43 U. CHI. L. REv. 192, 212-14 (1975).

11 In a few cases, the Government has successfully insisted on the inclusion of a so-called "asphalt clause" in an antitrust consent decree. The clause states that the defendant has violated the antitrust laws and that the consent decree will be prima facie evidence of that 
The question whether the entry of a consent decree requires the bilateral consent of the Government and the defendant is most likely to arise in one of two situations. First, where there is a bona fide disagreement regarding the necessity of certain items of relief, the Supreme Court case of United States v. Ward Baking Co. ${ }^{117}$ is controlling; it holds that a consent decree cannot be entered over the objections of the Government. The second situation-where there is agreement on what relief is necessary, but the Government insists on an admission of liability in order to aid private litigants-has proved to be more difficult. Several cases have held that the Government may refuse to enter into a consent agreement and force a trial unless the defendant admits its liability. ${ }^{118}$ In United States $v$. Brunswick-Balke-Collender Co. ${ }^{119}$ however, a district court in Wisconsin reached an opposite conclusion. Noting that the Government and the defendant had otherwise agreed on the proper relief, the court held that the Government could not insist to impasse on the inclusion of an admission-of-liability consent decree in light of the statutory purpose of section 5(a), and that even the most flagrant violator had an "unqualified right" to avoid "the prima facie sanction by capitulation." 120

Brunswick, which if followed would grant a defendant an "unqualified right" to enter into a consent decree and deprive private litigants of the benefits of a government judgment, can be criticized on at least two grounds. First, it cannot be reconciled with the legislative history of the Clayton Act. The purpose of the consent decree exemption was to aid the government enforcement machinery, not to grant defendants an unqualified right of avoidance. ${ }^{121}$ Second, permitting defendants to enter into a consent decree to which the Government was opposed would vitiate the ability of the Government to enforce the laws; if the rights of the accused to enter into a consent decree are superior to the Government's right to

fact in the future. United States v. Allied Chem. Corp., 1961 Trade Cas. 69,923 (D. Mass. 1960); United States v. Bituminous Concrete Ass'n, 1960 Trade Cas. 69,878 (D. Mass. 1960); United States v. Lake Asphalt \& Petroleum Co., 1960 Trade Cas. 69,835 (D. Mass. 1960).

${ }^{117} 376$ U.S. 327 (1964).

"18 See note 116 supra.

119230 F. Supp. 657 (E.D. Wis. 1962).

120 Id. at 664 .

121 See note 109 supra; Dabney, supra note 105, at 1062; Sullivan, supra note 105, at 840; Comment, Section 5 of the Clayton Act and Entry of Consent Decree Without Government Consent, 1963 Wis. L. Rev. 459, 462. But cf. Shores, supra note 3, at 444 (approving of Brunswick). 
negotiate, then the alleged violator will be able to establish the Government's prosecution policy.

The Government, therefore, should have discretion to reject a defendant's proposed consent decree in those few cases where it desires to expend its limited resources on litigation despite the defendant's willingness to capitulate. This flexibility is necessary both to allow the Government to aid potential private litigants ${ }^{122}$ as well as to enable the Government to litigate suits that it believes will establish important precedents. Where a consent decree is rejected by the Government and the defendant either admits liability or is unsuccessful in the ensuing trial, the defendant should be collaterally estopped from denying a violation of the antitrust laws in a subsequent treble damage suit. ${ }^{123}$

\section{Criminal Judgments}

In addition to its authority to seek injunctive relief, the Justice Department has statutory authority to bring criminal antitrust actions. ${ }^{124}$ In determining whether criminal convictions can have collateral estoppel effect in a subsequent civil action, distinctions must be drawn between jury verdicts, guilty pleas, and nolo contendere pleas.

1. Jury Verdicts of Guilty. There has been considerable dispute over whether, in general, guilty verdicts should be available for collateral estoppel purposes. ${ }^{125}$ When the parties are the same in successive suits, as when the Government follows a criminal conviction with a civil action, the general rule is that the prior judgment is conclusive between the parties. ${ }^{126}$ When the parties are not the 1955).

${ }_{122}$ Cf. United States v. Standard Ultramarine \& Color Co., 137 F. Supp. 167 (S.D.N.Y.

123 See cases cited note 116 supra. By admitting liability, the defendant would agree that the judgment would have conclusive rather than prima facie effect in a subsequent private action. It may be objected that according a forced admission collateral estoppel effect will produce more rather than less litigation since defendants would rather litigate than enter into such a decree. But this argument is highly speculative: the Government will not insist on admissions of liability in cases it does not want to try if it has reason to fear that the defendant would not capitulate under those terms. Also, where the defendant admits liability, litigation will be reduced.

i24 15 U.S.C. $\S \S 1-3$ (1970).

125 See generally Vestal \& Coughenour, Preclusion/Res Judicata Variables: Criminal Prosecution, 19 VAND. L. Rev. 683 (1966) [hereinafter cited as Vestal \& Coughenour].

i24 E.g., Moore v. United States, 360 F.2d 353 (4th Cir. 1965); Tomlinson v. Lefkowitz, 334 F.2d 262 (5th Cir. 1964), cert. denied, 379 U.S. 962 (1965). Thus where the Government first established a conspiracy in violation of the antitrust laws in a criminal action, the defendant was collaterally estopped from relitigating the existence of a conspiracy in a subse- 
same in the second suit, however, the courts have reached inconsistent results. At one time, the mutuality requirement barred the use of a prior criminal judgment as collateral estoppel in a subsequent civil proceeding not brought by the Government. ${ }^{127}$ But with the demise of the mutuality requirement, ${ }^{128}$ many state ${ }^{129}$ and federal ${ }^{130}$ courts have given criminal judgments conclusive weight in subsequent civil suits.

The modern tendency of allowing criminal judgments based on a verdict of guilty to have collateral estoppel effect should be followed in antitrust cases. If a civil judgment can be given conclusive weight in a subsequent civil suit, it follows that a criminal judgment should be given similar effect because of the higher burden of proof and greater safeguards in a criminal proceeding. ${ }^{131}$ No strong policy calls for preventing private antitrust plaintiffs from relying on a prior criminal antitrust conviction in a subsequent treble damage claim to establish a violation of the antitrust laws. ${ }^{132}$

2. Guilty Pleas. Despite some strong contrary dictum from earlier cases, ${ }^{133}$ it is now generally accepted that judgments based on guilty pleas can have prima facie effect under section $5(a)$ in subsequent treble damage suits. ${ }^{134}$ But, as in the case of criminal

quent civil injunctive suit brought by the Government. Teamsters Local 167 v. United States, 291 U.S. 293 (1934).

${ }^{127}$ Chatangco v. Abaroa, 218 U.S. 476, 481 (1910). See also, e.g., Brown v. Moyle, 133 Colo. 29, 290 P.2d 1105 (1955); Smith v. New Dixie Lines, Inc., 201 Va. 466, 111 S.E.2d 434 (1959); Interstate Dry Goods Stores v. Williamson, 91 W. Va. 156, 112 S.E. 301 (1922).

${ }_{123}$ See text and notes at notes 30-43 supra.

${ }^{129}$ Cardillo v. Zyla, 486 F.2d 473 (1st Cir. 1973); Bressan Export-Import Co. v. Conlew, 346 F. Supp. 683 (E.D. Pa. 1972); Teitelbaum Furs, Inc. v. Dominion Ins. Co., 58 Cal. 2d 601, 375 P.2d 439, 25 Cal. Rptr. 559 (1962); Newman v. Larsen, 225 Cal. App. 2d 22, 36 Cal. Rptr. 883 (Dist. Ct. App. 1964); Hurtt v. Stirone, 416 Pa. 493, 206 A.2d 624, cert. denied, 381 U.S. 925 (1965). But see Brooks v. State, 259 Ind. 678, 291 N.E.2d 559 (1973); Wheelock v. Eyl, 393 Mich. 74, 223 N.W.2d 276 (1974). A few jurisdictions hold that prior criminal convictions are admissible in a subsequent civil proceeding, but the prior judgment is not conclusive of issues determined. E.g., Asato v. Furtado, 52 Hawaii 284, 474 P.2d 288 (1970).

130 United States v. Frank, 494 F.2d 145, 160 (2d Cir.) (Friendly, J.), cert. denied, 419 U.S. 828 (1974) (dictum).

${ }^{131}$ See Teitelbaum Furs, Inc. v. Dominion Ins. Co., 58 Cal. 2d 601, 606, 375 P.2d 439, 441, 25 Cal. Rptr. 559, 561 (1962) (Traynor, J.).

${ }^{132}$ See Korman, supra note 6, at 84. But Korman believes judicial application of collateral estoppel is unlikely absent new legislation. See note 6 supra. The Supreme Court has observed that a court is to handle the difficult problem of determining what was resolved in the prior government criminal action by reviewing the record in its entirety including the pleadings, jury instructions, evidence submitted and opinions, if any. Emich Motors Corp. v. General Motors Corp., 340 U.S. 558, 569 (1951).

${ }^{133}$ See, e.g., Twin Ports Oil Co. v. Pure Oil Co., 26 F. Supp. 366 (D. Minn. 1939), aff'd on other grounds, 119 F.2d 747 (8th Cir.), cert. denied, 314 U.S. 644 (1941) (dictum).

13. Armco Steel Corp. v. North Dakota, 376 F.2d 206 (8th Cir. 1967); General Elec. Co. 
jury convictions, no sound policy requires that a guilty plea should be limited to prima facie effect. ${ }^{135}$ For purposes of collateral estoppel, the general rule is that both jury verdicts and guilty pleas are to have conclusive weight so that those who have exercised their right of self-defense will not be penalized for having done so. ${ }^{136}$ Even though allowing guilty pleas to have collateral estoppel effect is not free from all difficulty, ${ }^{137}$ the private antitrust plaintiff should be able to rely on prior government judgments in which the defendant pleaded guilty unless the defendant can establish that extenuating circumstances compelled the plea. ${ }^{138}$

3. Nolo Contendere Pleas. Unlike guilty pleas, nolo contendere pleas have consistently been held to fall within the consent

v. City of San Antonio, 334 F.2d 480 (5th Cir. 1964); City of Burbank v. General Elec. Co., 329 F.2d 825 (9th Cir. 1964); Commonwealth Edison Co. v. Allis-Chalmers Mfg. Co., 323 F.2d 412 (7th Cir. 1963), cert. denied, 376 U.S. 939 (1964); United States v. Englehard-Hanovia, Inc., 252 F. Supp. 605 (S.D.N.Y. 1964). But cf. Northwest Elec. Power Co-op, 30 F.R.D. 557 (W.D. Mo. 1961).

${ }^{135}$ Guilty pleas in antitrust cases, like such pleas in general, Dunham v. Pannell, 263 F.2d 725 (5th Cir. 1959); Dimmick v. Follis, 123 Ind. App. 701, 111 N.E.2d 486 (1953); Book v. Datema, 256 Iowa 1330, 131 N.W.2d 470 (1964), have been held admissible in subsequent suits as an admission against interest. See, e.g., Simco Sales Serv. v. Air Reduction Co., 213 F. Supp. 505, 507-08 (E.D. Pa. 1963).

${ }^{136}$ Vestal \& Coughenour, supra note 125, at 715; e.g., Brazzel v. Adams, 493 F.2d 489 (5th Cir. 1974); Metros v. United States Dist. Court, 441 F.2d 313 (10th Cir. 1970); Commonwealth Edison Co. v. Allis-Chalmers Mfg. Co., 323 F.2d 412 (7th Cir. 1963), cert. denied, 376 U.S. 939 (1964) (by implication); United States v. Guzzone, 273 F.2d 121 (2d Cir. 1959); Hooper v. Guthrie, 390 F. Supp. 1327 (W.D. Pa. 1975); United States v. Schneider, 139 F. Supp. 826 (S.D.N.Y. 1956); United States v. Ben Grunstein \& Sons, 127 F. Supp. 907 (D.N.J. 1955). But cf. Teitelbaum Furs, Inc. v. Dominion Ins. Co., 58 Cal. $2 d$ 601, 605-06, 375 P.2d 439, 441, 125 Cal. Rptr. 559, 561 (1962) (dictum) (guilty pleas should not have collateral estoppel effect because they may only reflect a compromise or a belief that paying a fine is more advantageous than litigation); 1B J. Moore, Federal Practice f| 0.418[1], at 2706 (2d ed. 1974). There are two strong incentives for an antitrust defendant not to plead guilty. First, guilty pleas are admissible as prima facie evidence in subsequent treble damage suits. See cases cited note 134 supra. Second, section 162(g) of the Internal Revenue Code of 1954 prohibits corporate defendants from deducting as a business expense the full amount of any judgment or settlement in a private antitrust suit if the defendant had earlier pleaded guilty or nolo contendere on the same set of facts.

${ }^{137}$ It will be difficult, in the subsequent suit, to determine how much of the indictment is admitted by the guilty plea. See Note, The Admissibility and Scope of Guilty Pleas in Antitrust Treble Damage Actions, 71 YaLE L.J. 684, 694-700 (1962).

${ }_{138}$ Professor Vestal suggests that the defendant should be given a chance to explain the circumstances surrounding his plea of guilty before he is prevented from relitigating. If the defendant could demonstrate that the plea represented a desire to avoid the cost and time of a trial rather than to admit guilt, then collateral estoppel would be inapplicable. See Vestal \& Coughenour, supra note 125, at 717. But see note 136 supra. Any increase in overall litigation that may result if defendants are forced to contest criminal charges should be more than offset by a corresponding simplification of subsequent civil litigation. Moreover, defendants who wish to capitulate without pleading guilty may attempt to plead nolo contendere (see text and notes at notes $139-47$ infra) to avoid being collaterally estopped in later suits. 
decree exception to the section 5(a) prima facie evidence sanction. ${ }^{139}$ At common law, nolo pleas lacked collateral estoppel effect. ${ }^{140}$ Thus, whether nolo pleas are viewed as a type of consent judgment or are viewed under the common law, it seems clear that they cannot be conclusive in later litigation. A more difficult question is whether an antitrust defendant can plead nolo as of right in order to control the weight to be given to his criminal conviction in subsequent actions.

Rule 11 of the Federal Rules of Criminal Procedure vests the trial judge with broad discretion to reject a nolo plea. ${ }^{141}$ In light of this discretionary power, the Justice Department has attempted to persuade courts to reject nolo pleas entered by defendants accused of so-called "hard-core" antitrust violations. ${ }^{142}$ Some courts have held that nolo pleas should be accepted uniformly to further the section 5(a) policy of encouraging capitulation, ${ }^{143}$ but others have rejected nolo pleas where the alleged violations were particularly flagrant. ${ }^{144}$ Neither view has dominated.

In deciding whether to allow an antitrust defendant to plead nolo, the courts should attempt to include a consideration of the two apparently contradictory policy objectives of section $5(\mathrm{a})$ in their

${ }_{130}$ City of Burbank v. General Elec. Co., 329 F.2d 825, 830-35 (9th Cir. 1964); Commonwealth Edison Co. v. Allis-Chalmers Mfg. Co., 323 F.2d 412, 414-15 (7th Cir. 1963), cert. denied, 376 U.S. 939 (1964); Atlantic City Elec. Co. v. General Elec. Co., 207 F. Supp. 620, 628-29 (S.D.N.Y. 1962); Northwest Elec. Power Co-op v. General Elec. Co., 30 F.R.D. 557 (W.D. Mo. 1961); Barnsdall Ref. Corp. v. Birnamwood Oil Co., 32 F. Supp. 308, 310-12 (E.D. Wis. 1940); Twin Ports Oil Co. v. Pure Oil Co., 26 F. Supp. 366 (D. Minn. 1939), aff'd on other grounds, 119 F.2d 747 (8th Cir.), cert. denied, 314 U.S. 644 (1941).

140 E.g., United States v. Norris, 281 U.S. 619, 622 (1930) (dictum); Hudson v. United States, 272 U.S. 451, 455 (1926) (dictum); Simco Sales Serv., Inc. v. Air Reduction Co., 213 F. Supp. 505, 507-08 (E.D. Pa. 1963). However, a conviction based on a nolo contendere plea may be admissible for such collateral purposes as impeachment of credibility. Pfotzer v. Aqua Sys., Inc., 162 F.2d 779 (2d Cir. 1947).

iti "A defendant may plead not guilty, guilty or, with the consent of the court, nolo contendere . . . " FED. R. CRIM. P. 11; see, e.g., United States v. Dorman, 496 F.2d 438 (4th Cir.), cert. denied, 419 U.S. 945 (1974) (district court's practice of uniformly rejecting nolo pleas except in tax evasion cases held not to be an abuse of discretion).

142 Seamans, First Aid to the Plaintiff, 32 ANTITRust L.J. 41, 46 (1966) [hereinafter cited as Seamans].

${ }^{143}$ E.g., United States v. Safeway Stores, Inc., 20 F.R.D. 451, 456 (N.D. Tex. 1957); United States v. Jones, 119 F. Supp. 288, 290-91 (S.D. Cal. 1954).

11 In United States v. Standard Ultramarine \& Color Co., 137 F. Supp. 167 (S,D.N.Y. 1955), for instance, the court rejected a nolo plea where the alleged violations of the Sherman Act extended over a nine year period and the alleged violation was for price-fixing, which is one of the more serious infractions of the Act. The volume of the defendant's business, in addition, was $\$ 30,000,000$ out of a total national market of $\$ 80,000,000$. Nolo pleas were also rejected by the court in the so-called "Electrical Equipment Cases" out of concern for the limited resources of the plaintiff State of California. See Note, Nolo Pleas in Antitrust Cases, 79 HaRv. L. Rev. 1475, 1481 (1966) [hereinafter cited as Nolo Pleas]. 
discretionary deliberation. ${ }^{145}$ Congress attempted to encourage private treble damage actions by helping injured parties carry their burden of proof. At the same time Congress also exempted consent judgments from section 5(a) in order to aid the government enforcement machinery. Congress evidently concluded that the interests of private plaintiffs should be sacrificed in certain circumstances to aid the overall government enforcement program. But if the Government, for whatever reason, wishes to expend its resources through litigation, the only operative policy of section 5(a) is the policy of aiding private plaintiffs; where this is true, the courts should not allow the defendant to frustrate the interests of private plaintiffs by pleading nolo. The courts should, therefore, grant the Government substantial deference when it contests a nolo plea and should exercise their discretion to compel the defendant either to plead guilty or attempt to prove his innocence at trial; either a plea of guilty ${ }^{146}$ or a conviction ${ }^{147}$ should, of course, have collateral estoppel effect according to the analysis presented in this comment.

There is, therefore, nothing in the law of collateral estoppel to preclude its application when a private antitrust plaintiff follows a successsful government injunctive action, criminal action, or FTC proceeding. Consent judgments and nolo contendere pleas, on the other hand, should not be accorded collateral estoppel effect, although the defendant should not have an unqualified right either to compel the entry of a consent judgment or to plead nolo. Where a defendant's proposed consent judgment or nolo plea is opposed by the Government, collateral estoppel should follow if the defendant either admits liability or litigates and loses.

\section{Collateral Estoppel and the Right to Trial BY JURY}

Of the three types of government antitrust prosecutions-an injunctive action, an action brought by the FTC, or a criminal action-only in the criminal action is the defendant entitled to a jury trial. ${ }^{148}$ Since the defendant in a private treble damage suit is enti-

${ }^{185}$ Seamans, supra note 142 , at 52 . One commentator has suggested that such factors as potential aid to treble damage plaintiffs, the government expense if the case goes to trial; whether or not there is a civil suit pending on the same facts which would give private litigants the same benefit as a criminal judgment, and the heinousness of the defendant's alleged crime should all be considered by a court in determining whether to accept a nolo plea. Nolo Pleas, supra note 144, at 1481-87.

i" See note 136 supra.

"17 See notes 129.30 supra.

w" U.S. CoNST. amend. VI. 
tled to a jury trial, ${ }^{149}$ it is necessary to determine whether allowing a prior government injunction or FTC order to have collateral estoppel effect in a subsequent treble damage suit violates the seventh amendment right to jury trial..$^{150}$

Under the traditional seventh amendment analysis, ${ }^{151}$ a government nonjury judgment could clearly be used in a subsequent jury trial as collateral estoppel without abridging the defendant's right to jury trial. The seventh amendment preserves, but does not extend, the right to jury trial as it existed at common law in 1791..$^{152}$ Since a common law defendant in 1791 was not entitled to have a jury hear issues that had been adjudicated in an earlier equitable proceeding, ${ }^{153}$ the historical test for determining the right to jury trial would not preclude the application of collateral estoppel in the antitrust context.

Recent Supreme Court cases, particularly Beacon Theatres, Inc. $v$. Westover, ${ }^{154}$ have complicated seventh amendment adjudication by recognizing that it will not always be sufficient to examine the common law of 1791 to determine whether there is a right to jury trial in a particular case. In Rachal $v$. Hill, ${ }^{155}$ the Fifth Circuit, ignoring the historical test but relying heavily on Beacon Theatres, held that a decree in a prior government action in equity could not have collateral estoppel effect in a subsequent private action at law without violating the defendant's right to jury trial. If Rachal is followed in the antitrust area, the private antitrust plaintiff will be unable to use a government judgment as collateral estoppel in a subsequent treble damage suit if the defendant did not have the right to a jury trial in the prior suit. In order to ascertain the desirability of such a result, this comment will analyze the correctness of Rachal in light of Beacon Theatres, basic policy considerations, and other cases.

147 Fleitman v. Welsbach Street Lighting Co., 240 U.S. 27 (1916).

150 The seventh amendment to the Constitution provides that, "In Suits at common law, where the value in controversy shall exceed twenty dollars, the right of trial by jury shall be preserved ....."

${ }^{151}$ See, e.g., Dimick v. Schiedt, 293 U.S. 474, 476 (1935).

$1325 \mathrm{~J}$. Moore, Federal Practice ๆ $38.08[5]$, at 83 (2d ed. 1974).

${ }^{153}$ Shapiro \& Coquilette, The Fetish of Jury Trial in Civil Cases: $A$ Comment on Rachal v. Hill, 85 HaRv. L. Rev. 442, 448-56 (1972) [hereinafter cited as Shapiro \& Coquilette]. The authors conclude that the historical inquiry "indicates that in the late eighteenth and early nineteenth centuries, determinations in equity were thought to have as much force as determinations at law and that the possible impact on jury trial rights was not viewed with concern .... If collateral estoppel is otherwise warranted, the jury trial question should not stand in the way." Id. at $455-56$.

154359 U.S. 500 (1959).

155435 F.2d 59 (5th Cir. 1970), cert. denied, 403 U.S. 904 (1971). 


\section{A. Beacon Theatres, Inc. v. Westover}

Beacon Theatres reflects the basic jury trial problems created by the merger of law and equity effectuated by the Federal Rules of Civil Procedure. ${ }^{158}$ At common law, a jury trial was available as of right in any action brought at law but not in equity. The seventh amendment, by preserving the right to jury trial in actions at law, maintained the distinction between legal and equitable causes of action. Although the merger of law and equity in the federal courts was not intended to affect the right to a jury trial, ${ }^{157}$ the merger nonetheless made it more difficult for the courts to determine when the right existed. Because of the merger, the liberal joinder provisions of the federal rules, ${ }^{158}$ and the compulsory counterclaim rule, ${ }^{159}$ it became common for legal and equitable claims to be presented in the same action. ${ }^{160}$ The lower courts, aware that the determination of one claim would act as collateral estoppel in the second on common questions of fact, split on the question of whether the legal or equitable claims should be heard first. ${ }^{161}$

The Supreme Court addressed the problem of proper trial sequence in Beacon Theatres. In this case, the plaintiff sought a declaratory judgment that certain transactions between it and the defendant were not in violation of the antitrust laws and sought to enjoin the defendant from instituting any antitrust action regarding the controversy pending completion of the plaintiff's action. The defendant counterclaimed at law for treble damages and demanded a trial by jury. Finding the issues raised by the complaint to be essentially equitable, the district court scheduled a bench trial of the equitable issues in advance of a jury trial on the treble

iss Rule 2 of the Federal Rules of Civil Procedure provides, "[T] of action to be known as 'civil action." "See generally Morris, Jury Trial Under the Federal Fusion of Law and Equity, 20 Texas L. Rev. 427 (1942).

${ }^{157}$ Rule 38(a) of the Federal Rules of Civil Procedure provides "[T]he right of trial by jury as declared by the Seventh Amendment . . . shall be preserved . . . inviolate." $5 \mathrm{~J}$. Moore, Federal Practice If 38.11[9], at 128.20 (2d ed. 1974).

iss Fed. R. Crv. P. 18.

iss FED. R. Civ. P. 13

two See discussion in Thermo-Stitch, Inc. v. Chemi-Cord Processing Corp., 294 F.2d 486, 488-89 (5th Cir. 1961).

161 Three competing rules emerged regarding sequence of trials. One line held that the determination of sequence of trial should be left to the absolute discretion of the trial judge. E.g., Orenstein v. United States, 191 F.2d 184, 190 (1st Cir. 1951). A second held that the nature of the "basic issue" should control. E.g., Reliance Ins. Co. v. Everglades Discount Co., 204 F.2d 937 (5th Cir. 1953). A third held that in the absence of special circumstances, common factual issues must be tried to a jury. E.g., Leimer v. Woods, 196 F.2d 828 (8th Cir. 1952). See generally Note, Federal Courts: Right to Jury Trial in Cases Involving Both Equitable and Legal Issues, 47 CaLIr. L. Rev. 760, 763 (1959). 
damage claim. The Ninth Circuit, after acknowledging that this sequence could limit the defendant's opportunity to litigate common factual issues before a jury, denied the defendant's motion for mandamus to vacate the district court's order. ${ }^{162}$

On certiorari, ${ }^{163}$ Justice Black, speaking for a five-member majority, ${ }^{164}$ stated that the Declaratory Judgment Act, ${ }^{165}$ which created a legal remedy where none had existed before, ${ }^{166}$ and the merger of law and equity in the federal courts, which eliminated the need for equity's traditional principle of refusing to divest itself of jurisdiction because of the subsequent availability of a legal remedy, substantially restricted equity's historic jurisdiction. ${ }^{167}$ Justice Black then observed that even though related equitable and legal claims were often to be tried in one action, the Federal Rules provide that "the right to jury trial shall be preserved inviolate."168 Thus where legal and equitable claims are joined in the same action, Justice Black stated, the trial court has only limited discretion in determining the sequence of trial, and "that discretion . . . must, wherever possible, be exercised to preserve jury trial."'169 The Court overruled the Ninth Circuit on the strength of this principle and held that mandamus should have issued because the trial sequence ordered by the district court would have unnecessarily prevented the defendant from litigating its legal claim before a jury. ${ }^{170}$ Beacon has come to mean that in cases involving both legal and equitable elements, there is a constitutional right to a jury trial on common factual issues absent extraordinary circumstances..$^{171}$

${ }^{162} 252$ F.2d 864, 874 (9th Cir. 1958), rev'd, 359 U.S. 500 (1959).

${ }^{163} 356$ U.S. 956 (1957).

18s Justices Harlan and Whittaker concurred in a dissent written by Justice Stewart. Justice Frankfurter did not participate.

${ }^{165} 28$ U.S.C. $\$ \S 2201,2202$ (1970).

${ }^{186}$ One of the main arguments in the dissent was that the Declaratory Judgment Act did not create an additional legal remedy but merely a new statutory remedy which could be either legal or equitable depending on the nature of issues presented. 359 U.S. 500, 514-15 (1959) (Stewart, J.).

167359 U.S. 500,509 (1959).

${ }^{188}$ Id. at 510; FED. R. Civ. P. 38(a).

169359 U.S. at 510.

iza Id. at 508.

171 McCoid, Procedural Reform and the Right to Jury Trial: A Study of Beacon Theatres, Inc. v. Westover, 116 U. PA. L. REv. 1, 4 (1967) (citing cases at 5 n.18). McCoid suggests that Beacon Theatres is therefore a "striking departure from history" since equity could no longer adjudicate an issue material to requested equitable relief if that issue was also material to requested legal relief. Id. at 5. 


\section{B. The Interpretation of Beacon Theatres in Rachal v. Hill}

In Rachal $v$. Hill, ${ }^{172}$ the plaintiff brought a civil action to recover damages sustained as a result of violations of the federal securities laws. The district court found that the defendant's liability had been established in a prior injunctive action brought by the Securities Exchange Commission. Finding that the defendants had had a full and fair opportunity to litigate the liability issue, the district court granted summary judgment for the plaintiffs, holding that the defendants were collaterally estopped from denying liability.

The Fifth Circuit reversed, but expressly refused to base its holding that collateral estoppel was improper on the grounds that the mutuality requirement had not been satisfied. Finding no case directly on point, ${ }^{173}$ the court observed that Beacon Theatres had established the principle that a litigant has a right to have legal claims tried first to a jury in an action where legal and equitable claims are joined. ${ }^{174}$ The court concluded it would be "anomalous" after Beacon Theatres to hold that a litigant could lose his constitutional right to a jury trial because of a prior adverse determination in an equitable, nonjury proceeding. ${ }^{175}$ Rachal thus extends the defendant's ability to protect his right to a jury trial where legal and equitable claims are present in one action to the situation where the equitable action is concluded before the legal action has even begun. ${ }^{176}$

172435 F.2d 59 (5th Cir. 1970), cert. denied, 403 U.S. 904 (1971).

173 The Rachal court distinguished an earlier case in its own circuit, Painters Dist. Council 38 v. Edgewood Contracting Co., 416 F.2d 1081 (5th Cir. 1969), which held that issues litigated in a prior equitable action could have collateral estoppel effect in a subsequent action at law between the same parties. Rachal distinguished Painters on two grounds. First, the court distinguished Painters on its facts, observing that since the parties there were the same in both the first and second actions that case had not "raise[d] the special considerations required to insure justice in cases where mutuality of parties is lacking . . . ."435 F.2d at 63 n.5. Second, the court observed that the right to jury trial issue had not been raised in Painters. Id. at 63 n.5.

Although the court's factual distinction is correct, it is not a convincing ground for distinction in light of the general demise of the mutuality requirement acknowledged earlier in the Rachal opinion. Moreover, the Rachal opinion did not cite two district court opinions that addressed the jury trial issue and reached results contrary to its own. Mitchell v. Michigan-U.S. Industrial Glove \& Laundry Co., 189 F. Supp. 411 (E.D. Mich. 1960); William Whitman Co. v. Universal Oil Prods. Co., 92 F. Supp. 885, 888 (D. Del. 1950).

i74 435 F.2d at 64 .

${ }^{173}$ Id. Under Rachal, section $5(a)$ itself is arguably unconstitutional since it makes a prior equitable determination prima facie evidence in a subsequent legal proceeding. See Shapiro \& Coquilette, supra note 153 , at 457.

is $A$ third possible situation is where two suits regarding the same action are being litigated separately at the same time. In Goldman, Sachs \& Co. v. Edelstein, 494 F.2d 76 (2d Cir. 1974), a government and a private action were pending concurrently. The defendants in 
Although Rachal's reliance on Beacon Theatres has a certain initial attractiveness, Beacon Theatres does not in fact support the Rachal holding. ${ }^{177}$ The Court in Beacon Theatres assumed that a judgment from an equitable proceeding could estop a defendant in a subsequent legal action and thereby deprive him of the right to a trial by jury on issues common to both actions. ${ }^{178}$ Were this not the case, the sequence in which the equitable and legal claims were heard would not have troubled the Court. Similarly, the holding limiting the trial court's discretion in determining the trial sequence in order to protect the right to jury trial makes no sense unless it is understood that a prior equitable proceeding can have collateral estoppel effect in a later action at law. Beacon Theatres only attempted to sort out the difficult problem of determining the sequence of trial when legal and equitable claims are joined in the same action. It did not, as the Rachal court suggests, also alter the law of collateral estoppel ${ }^{179}$ to preclude an equitable determination from having collateral estoppel effect in a subsequent action at law.

The Court has, in cases since Beacon Theatres, reinforced the assumption that an equitable judgment can be asserted as collateral estoppel in subsequent legal actions. In both Dairy Queen, Inc. v. Wood ${ }^{180}$ and Meeker v. Ambassador Oil Corp. ${ }^{181}$ the Court held,

a civil action filed a petition for a writ of mandamus to stay the nonjury trial until completion of the jury trial. The court granted mandamus to foreclose the "potential destruction of the defendant's right to a jury trial." Id. at 78. The dissent, citing Rachal, argued that mandamus was unnecessary since "one who timely requests the right to a jury trial will not be collaterally estopped from exercising it by earlier resolution of the issues in a non-jury trial." Id. at 79. See Comment, Goldman, Sachs \& Co. v. Edelstein: The Application of Collateral Estoppel Principles in Derogation of the Right to Jury Trial, 1974 DukE L.J. 970.

in See Shapiro \& Coquilette, supra note 153.

178 As Judge Friendly stated in Crane Co. v. American Standard, Inc., 490 F.2d 332, 342 (1973):

The very basis of Beacon Theatres was that the effect of a trial of the equitable claim "could be, as the Court of Appeals believed, "to limit the petitioner's opportunity fully to try to a jury every issue which has a bearing on its treble damages suit" " . . . It was to avoid this preclusive effect that the Supreme Court directed initial trial of the legal counterclaim. (emphasis added)

See Katchen v. Landy, 382 U.S. 323, 339 (1966); Shapiro \& Coquilette, supra note 153, at 446; Note, supra note 161, at 763; Comment, Civil Procedure-Right to Jury Trial of Factual Issues Common to Both Legal and Equitable Claims, 45 Iowa L. Rev. 603, 604 (1960); Comment, Federal Courts-Right to a Jury Trial in Civil Actions Involving Equitable Claims, 38 Mo. L. Rev. 719, 722 (1973); Comment, Discretionary Jury Trial Under the Federal Rules, 17 WASH. \& LEE L. REv. 93 , 98 (1960).

${ }^{179}$ This logical extension of Rachal would compel the overruling of cases holding that equitable judgments can be asserted as collateral estoppel in a subsequent legal proceeding. E.g., Brady v. Daly, 175 U.S. 148 (1899); see Katchen v. Landy, 382 U.S. 323 (1966); RESTATEMENT OF JUDGMENTS $§ 68$, comment $j$ (1942).

180369 U.S. 469 (1962).

$18 \mathrm{st} 375$ U.S. 160 (1963). 
under Beacon Theatres, that the legal claims in those actions had to be adjudicated prior to the equitable ones. Again, these cases can only be understood if the right to jury trial can be foreclosed by a prior equitable determination. In Katchen $v$. Landy, ${ }^{182}$ the Court finally made this assumption explicit. In holding that bankruptcy courts were empowered to try equitable claims prior to legal ones, the Court observed:

Both Beacon Theatres and Dairy Queen recognized that there might be situations in which the Court would proceed to resolve the equitable claims first even though the results might be dispositive of the issues involved in the legal claim. ${ }^{183}$

In other words, the Supreme Court indicated in Katchen that Beacon Theatres is not to be read, as the Rachal court assumed, as foreclosing the use of an equitable judgment as an estoppel in a legal action but rather as an attempt to regulate trial sequence in a consolidated action so as to protect the right to jury trial whenever possible.

\section{A Policy Evaluation of the Rachal Extension of the Seventh Amendment}

The protection afforded to the right to jury trial by the Supreme Court in Beacon Theatres and subsequent cases has been relatively costless in terms of judicial economy. Since the doctrines of res judicata and collateral estoppel will ensure that issues common to both the legal and equitable claims will be tried only once, a rule designed to protect the right to jury trial in cases presenting legal and equitable claims will not produce substantial diseconomies. The percentage of cases tried to a jury will undoubtedly be increased by Beacon Theatres, but this additional cost will be sharply limited by the fact that the issues resolved by the jury will not be retried in an action involving either of the parties or their privies.

The Rachal holding, on the other hand, would generate substantial diseconomies by guaranteeing a defendant the right to have a jury rehear issues previously decided against him in an equitable action with a different party. Foreclosing the second plaintiff from using offensive collateral estoppel in this situation will generate the obvious costs of duplicative litigation. Moreover, the Rachal rule will increase overall litigation even further by giving plaintiffs an incentive not to join in one action all the defendants against whom

182382 U.S. 323 (1966).

183 Id. at 339 . 
they have related claims. ${ }^{184}$ If a plaintiff has a legal claim against one defendant and a related equitable claim against another, it will be in his best interests not to join both defendants in the first action but to bring the equitable action first. By doing so, the plaintiff will be able to litigate the equitable claim without prejudice to his ability to bring the legal action; the equitable judgment cannot be asserted as collateral estoppel in the legal action under the Rachal reading of the seventh amendment because a jury had not had an opportunity to hear the common claims in the prior case.

The Rachal case, moreover, threatens to impose an even more staggering diseconomy into the judicial system than those outlined above. The Rachal court offered no convincing reason why the rule it enunciated should be limited to cases involving a new party. ${ }^{185} \mathrm{~A}$ litigant who has had an issue determined against him in an equitable proceeding is deprived of his right to a jury trial just as surely if he is estopped from relitigating that issue in a legal action against the same party, as if he is prevented from doing so with a different party. ${ }^{186}$ The Rachal result, carried to its logical conclusion, would substantially erode the doctrines of res judicata and collateral estoppe ${ }^{187}$ and would produce a tremendous amount of needless relitigation. The Rachal extension of the seventh amendment is thus as unsound on policy grounds as it is in its reliance on Beacon Theatres. ${ }^{188}$ The defendant's constitutional right to a jury trial should not prevent the application of collateral estoppel when a private antitrust plaintiff follows a successful government judgment.

\section{Rachal's Progeny: McCook v. Standard Oil Co. of California}

In McCook v. Standard Oil Co. of California, ${ }^{189}$ a federal court

Is See text and notes at notes 70-73 supra.

185 See note 173 supra.

188 It has been suggested that it would be desirable to extend the Rachal holding to the two-party situations. See 40 U. CiN. L. REv. 373, 381 (1971).

187 See note 179 supra.

${ }_{188}$ The dubious theoretical underpinnings of Rachal help to explain its mixed reception in the federal courts. Compare Lynne Carol Fashions, Inc. v. Cranston Print Works Co., 453 F.2d 1177, 1184 (3d Cir. 1972) (arbitration proceeding where no right to jury trial existed not given collateral estoppel effect in later damage suit), and Cannon v. Texas Gulf Sulphur Co., 323 F. Supp. 990, 994 (S.D.N.Y. 1971) (SEC action in which all parties waived their right to a jury trial not given collateral estoppel effect in subsequent damage suit), with Crane Co. v. American Standard, Inc., 490 F.2d 332, 343 n.15 (2d Cir. 1973) (Rachal criticized in dictum) (Friendly, J.). The opinion in Goldman, Sachs \& Co. v. Edelstein, 494 F.2d 76 (2d Cir. 1974), which did not mention Rachal, can be viewed as implicitly rejecting its basic principle that equitable decrees cannot have collateral estoppel effect in a subsequent action at law. See generally Comment, supra note 176.

${ }^{189} 393$ F. Supp. 256 (C.D. Cal. 1975). 
was recently faced for the first time with the applicability of Rachal when a private antitrust plaintiff follows a successful government equitable judgment. Claiming that section 5(a) did not oust the doctrine of collateral estoppel, the plaintiff argued that the prior government judgment should collaterally estop the defendant from denying that it had violated the antitrust laws. The court, rejecting the plaintiff's contention, held, as in Rachal, that the defendant was entitled to a jury trial on all legal issues. ${ }^{190}$ But the court, perhaps recognizing the weak foundation for the Rachal principle, elected not to base its decision on Rachal's reading of the seventh amendment. Rather, the court stated, because of the "public policy in favor of jury trials growing out of the Seventh Amendment," Rachal could be read as creating a "judicial policy exception to the general doctrine of collateral estoppel," not mandated by the seventh amendment, but by notions of basic fairness. ${ }^{191}$

The court's opinion rests on the dubious assumption that there is a public policy favoring jury trials emanating from the seventh amendment, but nevertheless independent of it and ignores that as a historical matter this policy has been inextricably bound with the seventh amendment. ${ }^{102}$ Where there is no constitutional right to a jury trial, moreover, it is difficult to justify imposing such a right on policy grounds. ${ }^{193}$ When a private antitrust plaintiff follows a successful government judgment, the policy justifications for allowing the defendant to relitigate issues determined in the government action before a jury are tenuous at best. The $M c C o o k$ court asserts that it would be unjust to estop the defendant from relitigating his liability in this situation. ${ }^{194}$ But it is hard to understand what would be unjust about estopping the defendant from relitigating issues which he already has had a full and fair opportunity to litigate. ${ }^{195}$ If the $M c C o o k$ court was implying that an equitable determination is in itself so inherently unreliable that it does not afford litigants a "full and fair opportunity" to be heard, then the court was implic-

${ }^{150}$ Id. at 259 . By basing its holding on the right to jury trial, the court declined to decide whether the doctrine of collateral estoppel had been ousted by section $5(a)$.

19! Id.

192 See Ross v. Bernhard, 396 U.S. 531 (1970); Simler v. Conner, 372 U.S. 221, 222 (1963); Jacob v. City of New York, 315 U.S. 752 (1942); Baylis v. Traveller's Ins. Co., 113 U.S. 316 (1885); Parsons v. Bedford, 28 U.S. (3 Pet.) 433 (1830).

${ }^{133}$ Although the Supreme Court has acknowledged that policy considerations might call for curtailing the right to jury trials, it has found these policy considerations "insufficient to overcome the clear command of the Seventh Amendment." Curtis v. Loether, 415 U.S. 189, 198 (1974).

1" McCook v. Standard Oil Co. of California, 393 F. Supp. 256, 259 (C.D. Cal. 1975).

${ }^{10 s}$ Cf. Blonder-Tongue Laboratories, Inc. v. University of Illinois Foundation, 402 U.S. 313 (1971). 
itly advocating drastically revamping the law of collateral estoppel and res judicata-it would be just as unfair to allow an equitable judgment to be the basis of res judicata or collateral estoppel in the two-party situation if this assumption were correct. Thus the policy that seeks to support the $M c C o o k$ principle requires extending the case to situations where its application would be intolerable.

Recognition of a right to jury trial independent of the seventh amendment would promote other diseconomies as well. Jury trials are more expensive and cumbersome than bench trials. ${ }^{196}$ Moreover, by depriving the government injunction of collateral estoppel effect in subsequent legal actions, the $M c C o o k$ doctrine encourages relitigation where the Constitution does not require it and discourages private enforcement of the antitrust laws. In the final analysis then, the public policy favoring jury trials does not provide a more satisfactory basis than the seventh amendment for denying government equitable judgments collateral estoppel effect in subsequent legal suits.

\section{CONCLUSION}

Section 5(a) of the Clayton Act provides that a judgment or decree shall be prima facie evidence "as to all matters respecting which said judgment or decree would be an estoppel as between [the defendant and the Government]." Section 5(a) was passed to stimulate private enforcement of the antitrust laws at a time when, because of the principle of mutuality of estoppel, private litigants could derive no benefit from a prior government judgment. Since the mutuality requirement has been largely abandoned, the successful prior government judgment which once would have had no effect in a subsequent private action would now have conclusive effect in the absence of section 5(a). Nevertheless, the courts have continued to give this remedial statute a restrictive interpretation and have limited the effect of prior government judgments to prima facie evidence. The irony is apparent-a statute which was designed to aid private antitrust litigants now deprives this supposedly preferred class of litigants of a right to which they would otherwise be entitled. This result is not required by the text or legislative history of the Clayton Act, the law of collateral estoppel or the right to jury trial. In fact, it will be possible to achieve section 5(a)'s aim of aiding private enforcement of the antitrust laws only if the courts

${ }^{196}$ See generally Shapiro \& Coquilette, supra note 153 , at note 60 . 
recognize that they may and should allow private antitrust plaintiffs to assert prior government judgments as collateral estoppel in subsequent actions.

Daniel R. Fischel 